NBER WORKING PAPER SERIES

\title{
FROM EMPTY PEWS TO EMPTY CRADLES: FERTILITY DECLINE AMONG EUROPEAN CATHOLICS
}

\author{
Eli Berman \\ Laurence R. Iannaccone \\ Giuseppe Ragusa \\ Working Paper 18350 \\ http://www.nber.org/papers/w18350
NATIONAL BUREAU OF ECONOMIC RESEARCH
1050 Massachusetts Avenue
Cambridge, MA 02138
August 2012

We appreciate the comments of Alicia Adsera, Evelyn Lehrer, seminar participants at the NBER Labor Studies meetings, George Mason University, USC, UC Irvine, the Southern California Applied Economics workshop at UCLA, Duke NIH demographic meetings at UCLA, Brown, UCLA, the European Economic Association meetings, UC Santa Barbara, the Society of Labor Economics meetings, UC San Diego, Population Studies at Michigan, the Harris School, University College London, an ASSA session, and a session of the Association for the Study of Religion, Economics and Culture (ASREC). Tiffany Chou and Liang Choon Wang provided expert research assistance. We acknowledge the support of National Science Foundation grant 0520188 through the National Bureau of Economic Research. The views expressed herein are those of the authors and do not necessarily reflect the views of the National Bureau of Economic Research.

NBER working papers are circulated for discussion and comment purposes. They have not been peerreviewed or been subject to the review by the NBER Board of Directors that accompanies official NBER publications.

(C) 2012 by Eli Berman, Laurence R. Iannaccone, and Giuseppe Ragusa. All rights reserved. Short sections of text, not to exceed two paragraphs, may be quoted without explicit permission provided that full credit, including $\odot$ notice, is given to the source. 
From Empty Pews to Empty Cradles: Fertility Decline Among European Catholics

Eli Berman, Laurence R. Iannaccone, and Giuseppe Ragusa

NBER Working Paper No. 18350

August 2012

JEL No. H31,H41,I3,I38,J13,J4,Z12

\begin{abstract}
$\underline{\text { ABSTRACT }}$
Catholic countries of Europe pose a demographic puzzle -fertility is unprecedentedly low (total fertility=1.3) despite low female labor force participation. We model three channels of religious effects on demand for children: through changing norms, reduced market wages, and reduced costs of childrearing. We estimate their effects using new panel data on church attendance and clergy employment for thirteen European countries from 1960-2000, spanning the Second Vatican Council (1962-65). Catholic theology is uniform across countries. Yet service varied considerably across countries and over time, especially before the Council, reflecting differences in Church provision of education, health, welfare and other social services. We use differential declines in service provision --measured by nuns/capita-- to identify its effect on fertility, controlling for secular trends. They are large: 300 to 400 children per nun. Reduced religiosity (measured by church attendance) has no effect for Protestants, but predicts fertility decline for Catholics. The data suggest that service provision and religiosity complement each other -a finding consistent with preferential provision of services to church attendees. Nuns outperform priests in predicting fertility, suggesting that the childrearing cost channel dominates theology and norms.
\end{abstract}

Eli Berman

Department of Economics, 508

University of California, San Diego

9500 Gilman Drive

La Jolla, CA 92093

and NBER

elib@ucsd.edu

Laurence R. Iannaccone

Chapman University

1 University Drive Orange, CA 92866

iannacco@chapman.edu
Giuseppe Ragusa

LUISS Guido Carli University

Viale Pola 12, 00198 Roma, Italia

gragusa@luiss.it 


\section{Introduction}

Birth rates fell so rapidly in the 1970s and 1980s in Southern Europe that in a generation it went from Europe's highest fertility region to its lowest. Unless total fertility (now below 1.4 children per woman) increases substantially, the native-born population is destined to further age and shrink. This phenomenon has been noted by many scholars (Munoz-Perez, 1989, studies fertility in Italy, Greece, Portugal and Spain in detail.) An aging and shrinking population has major economic implications, generating demand for young immigrant workers and threatening the solvency of "pay as you go" social insurance funds. Italy and Spain, for instance, are projected to have one retiree for each working age person by the year 2050. Increased morbidity implied by an aging population will also strain the funding of publicly provided health care.

Should Europe's experience reflect general consequences of economic development and social change, then understanding why fertility declined in Southern Europe is important for projecting global population. The consequences of policies concerning immigration, education, health and retirement all depend upon population trends. Yet credible demographic projections require reliable models, and demographers remain puzzled by the causes of European fertility decline. Particularly surprising is that Southern European fertility has declined since 1960 without a rapid increase in female labor force participation (Bettio and Villa, 1998; Ahn and Mira, 2002), so that Southern Europe currently has historically low rates of both fertility and female participation. In Spain and Italy, total fertility has fallen below 1.3 and female labor force participation remains under $40 \%$ - both well below European averages. This pattern defies the standard economic fertility model of Becker and Lewis (Becker and Lewis, 1973; Becker, 1991), is unprecedented in the history of fertility transition, and is not resolved by considering plausible economic factors such as housing prices or women’s education (Del Boca, 2002).

Our approach to this puzzle involves religion, and in particular the effects of Catholic service provision on fertility. For an indication of Catholicism's possible relevance, Figure 1 plots the development of total fertility rates (TFR) for three categories of Western European nations: the Catholic countries (with more than $70 \%$ of the population Catholic - Belgium, Ireland, Italy, Luxembourg, Portugal, Spain,); the Protestant (with $70 \%$ or more Protestants Denmark, Norway, Sweden and the UK); and other countries (with neither religion dominant or with a history of strong separation between religious and national institutions - France ${ }^{2}$, Germany, Greece, Netherlands and Switzerland). The strongly Catholic countries had fertility almost a half child per woman higher than the other countries in the 1970s. Yet fertility in those countries declined so rapidly in the 1970s and 1980s that by the 1990s they averaged the lowest fertility in Europe, about half a child less than that of the Protestant countries.

Why did fertility decline so rapidly in those very Catholic countries? A general decline in religiosity cannot be the explanation. Since the 1960s Protestant countries have experienced a more rapid decline in Church attendance than Catholic. Nor can the explanation be a change in

\footnotetext{
${ }^{2}$ Since the French Revolution, French governments have repeatedly limited the activities of the Catholic Church, particularly the service provision most relevant to this study. Hence, "by the end of the nineteenth century, the Church had lost all connection to the French state, religious instruction was forbidden, and religious orders were forbidden to teach in private schools” (Warner 2000: 62, c.f. Lee and Piveteau 1967). Wilde (2007) emphasizes that French Bishops at the Second Vatican Council were strongly allied with the Northern European ecumenical reformers rather than with the conservatives from the other majority Catholic countries.
} 
Catholic theology about birth control, or a reduction in personal compliance with that theology. We will argue that there was no such change, and even if there were, it would have been common to Catholics.

We offer an alternative explanation: the Catholic Church retreated in the mid 1960s from providing a variety of family-friendly services which had previously lowered the cost of raising children for Catholic families. Attrition of nuns in the aftermath of the Second Vatican council (Vatican II) resulted in the decline of those services, raising the cost of childrearing and thus reducing fertility.

Consistent with this explanation, our empirical results show that cross-country variation in the decline in nuns per Catholic, --a decline we argue was caused by Vatican II (1962-65)-- is a strong predictor of differential fertility decline in European countries between 1960 and 2000. The variance underlying that inference comes from the interaction of cross-country variation in the pre-Council level of nuns per Catholic with post-Vatican II attrition of nuns, which has slightly different timing across countries.

Catholic religiosity also declines sharply after the Council. Declining religiosity, as measured by church attendance, does not predict declining fertility for Protestants but does predict fertility decline for Catholics. Among Catholics, the effect of reduced religiosity seems to be particularly strong when service provision is high, suggesting complementarity. That is consistent with the predictions of a club model, in which services are provided preferentially to members who display religiosity. Services provided by priests are a poorer predictor of fertility than those provided by nuns, suggesting that social services dominate theological services. Nuns seem to increase fertility by a remarkable 300 to 400 children per nun.

These results have strong implications for public policy, as they indicate that the availability of relatively inexpensive, family-friendly services has sharp effects on fertility, with each additional service provider predicting hundreds more children born.

The paper proceeds as follows: Section 2 briefly survey the literature on religion, economics, and fertility, and sets out our conjectures in detail. Section 3 describes institutional aspects of the Catholic Church, including the Second Vatican Council. In Section 4 we provide a simple framework for estimation which allows religious institutions to affect fertility through both theological and service provision channels. Section 5 describes our data, Section 6 reports estimation results and Section 7 concludes.

\section{Literature}

Our approach assimilates insights from two literatures: economic demography, and religious approaches to fertility. The classic contributions to economic demography explain the importance of childhood mortality and female labor force participation (Becker and Lewis, 1973; Becker, 1991). Becker's quality-quantity theory emphasizes the role of rising female earnings in increasing the cost of raising numerous children relative to that of child "quality" (education, health, etc.), inducing mothers to give birth to fewer children while investing more resources invested in each child. Yet female labor force participation is now associated with relatively high 
fertility across countries in Europe, contradicting the prediction of the Becker model. Childhood mortality rates are low and stable in Europe so they cannot explain falling fertility either.

Bongaarts (1999) suggested that uniquely low European total fertility rates in the 1990s may underpredict eventual fertility, and that women will compensate later in life for the low fertility of their 20s. Yet we have not observed any recovery in total fertility rates as those women have reached their 50s, making a subsequent fertility increase unlikely. Daniela Del Boca $(2002,2003)$ has argued that Southern European labor market institutions are very unfavorable to working mothers, with poor provision of child care and few part time jobs available with benefits. She argues that rather than work or raise children, young women wait (typically living with parents) until they obtain a job that accommodates motherhood. de Laat and Sevilla-Sanz (2004) offer an analogous explanation based on norms, arguing that Southern European fathers are less willing to care for children, increasing the shadow cost of child rearing for potential working mothers and augmenting the substitution effect of rising women's wages on fertility. Giuliano (2007) links the gender role attitudes of Southern Europeans to low labor force participation in both Europe and the U.S. Given the Catholic Church's historic role in providing institutional and normative support for fertility and childrearing, our theory offers an alternative but complementary set of explanations.

Multiple studies have linked religiosity and fertility (Stolzenberg, Bair-Loy, et al. 1995), with particular attention to Southern Europe (Lehrer 1995; Lehrer 1996). Differential fertility changes among Catholics and Protestants in the U.S. have been studied extensively. Westoff and Jones (1979) showed that Catholics experienced an amplified baby boom - higher completed fertility in the 1950s (by about a child per family), followed by rapid fertility decline in the 1960s and 1970s which eliminated the Catholic / Non-Catholic fertility differential by the mid 1970s. They also report that among Catholics, religiosity, (as measured by communion) was associated with higher fertility in the 1950s and 1960s but not in the 1970s. Rosenzweig and Schultz (1985) found that Catholics have more children even after adjusting for other socioeconomic factors, such as maternal education. Sander (1992) takes issue with a causal interpretation of the effect of Catholicism on fertility, reporting evidence that couples who prefer large families are more likely to remain Catholic or convert to Catholicism.

Research by Adsera (2004) examines the role of religion and religiosity in Spain. Using data from the 1985 and 1999 Spanish Fertility Surveys, she finds that practicing (i.e., observant) Catholics had no higher fertility than non-practicing Catholics in the mid-1980s. Yet by the late1990s, after 15 years of decline in practice, the remaining practicing Catholics do have higher fertility. A companion paper using International Social Survey Program (ISSP) data shows that Spain in 1985 may be an anomaly (Adsera, 2006). In the thirteen OECD countries surveyed by the 1994 ISSP, higher church attendance is associated with significantly higher desired fertility in all countries for women and in all but two countries for men. This leaves open the possibility that a decline in religiosity has contributed to declining fertility in highly Catholic countries besides Spain.

Club-theoretic models drawn from the economics of religion predict that communallyoriented "sectarian" religions will tend to have high fertility even in the absence of explicit pronatalist theology because they induce women to voluntarily adopt a set of religious 
prohibitions which allow the group to effectively provide a set of local public (club) goods. Those prohibitions turn out to be pronatalist because they distance women from secular consumption and labor markets, lowering the opportunity cost of childrearing. ${ }^{3}$ Catholicism is certainly not a sectarian religion, but if religiosity can have large effects on fertility among sects through social service provision, it should not be surprising to see fertility effects of religiosity even in a mainstream religion with less strict prohibitions and practices.

\section{The Second Vatican Council and Fertility}

\section{The Social Consequences of Communal Religion}

Most religious groups endorse fertility, so cross-group variation might come more from the ability to implement high fertility norms. Scholars have long recognized that collective activities (in addition to supernatural beliefs) underpin a religion's capacity to constrain behavior and maintain institutions. They have also recognized that some religions are more strongly collective than others. Adam Smith (1965: 748-750) observed that "strict or austere" systems of morality are far more common in "little religious sects" than in government-regulated "established churches." Subsequent generations of scholars developed insights like these into a full-blown theory of religious organization. The famous sociologist Emile Durkheim (1965: 62) argued that collectivity explained how "religion,"but never "magic," could sustain "moral communities" governed by "unified systems of beliefs and practices."

For European sociologists of the 19th and early-20th centuries, a stronger communal orientation likewise distinguished Catholicism from mainstream (state-church) Protestantism. The social consequences of this difference ranged from lower rates of suicide among Catholics (Durkheim, 1965) to more rapid economic development among Protestants (according to Weber (1946)). Despite lingering debate over the these particular inferences, most religious researchers broadly agree that the Catholic Church traditionally promoted stronger group identity and sustained a broader array of institutions than any Protestant State Church.

The scholarly consensus about Catholicism, communalism, and behavioral constraints suggests that fertility might well be another behavior sustained more effectively by Catholicism

\footnotetext{
3 That argument starts with Iannaccone's (1992) model of religious sects as clubs that provide quasi-public services to members. To limit free-rider problems, such groups impose prohibitions, so-called "stigmas," that indirectly tax (non-group) market activities. At the margin, members respond by shifting hours away from the labor force and into non-market activities which benefit the club. Because of the positive externalities associated with club activities, those prohibitions actually benefit club members. The club model provides a coherent rational-choice theory that explains otherwise puzzling behavior of strict sectarian denominations. It also rationalizes more mild prohibitions characteristic of merely "conservative” churches such as contemporary evangelical Protestants, traditional Catholics and Orthodox Jews. Berman (2000) marries the club approach to Becker’s (1991) theory of fertility, showing that prohibitions increase the effective tax on market labor, thereby reducing real wages. The effect of these prohibitions for women is to make investments of market resources in child "quality" more difficult to achieve while making quantity more attainable, with a resulting increase in fertility. (For a formal derivation, see Berman (2000) or Berman and Stepanyan (2003). High fertility is in fact associated with sectarianism among Christians, UltraOrthodox Jews (Berman, 2000), and Radical Islamists (Berman, 2009). This could be due to mechanisms at either the individual or the group level. Berman (2000) shows that increased subsidies to the group induced dramatic fertility increases of one or two children per woman over a decade among Israeli Ultra-Orthodox Jews. This suggests a group-level mechanism as predicted by the club model, particularly since this rapid fertility increase occurred without any change in Orthodox Jewish theology regarding births or birth control.
} 
than Protestantism. Official Catholic doctrine favors fertility (and opposes all forms of birth control and abortion) and Catholicism traditionally was associated with large family size.

\section{The Second Vatican Council and Declining Catholic Religious Activity}

The Second Vatican Council (Vatican II) trigged broad-based decline within Catholicism. The losses included reductions in the number of people becoming (or remaining) priests, even larger reductions in the number of nuns, reduced mass attendance among the Catholic laity, and increased willingness among Catholics to question official doctrine, including prohibitions on divorce and birth control (Hout and Greeley 1987; Greeley 1989; Schoenherr and Young 1993: 10-12; Stark and Finke 2000: 169-190). Although scholars continue to debate why Vatican II had these effects, the decline itself is universally acknowledged.

Vatican II is generally viewed by scholars as the massive exogenous shock, more consequential (and unanticipated) than any other change to Catholicism in the past several centuries. ${ }^{4}$ Both contemporaneous and historical accounts stress its radical and surprising character - particularly for parish priests, nuns, and ordinary Catholics (Dolan 1985: 421-454; Hoge and Wenger 2003: 7-12). The Pope who initiated Vatican II was 77 years old when elected in 1958 and widely regarded as an interim "caretaker" (he indeed died less than five years after election). Only one other general council had ever been called - in 1870 - and its effect had been to resist change and reaffirm Church tradition. Thus, even those who applauded Pope John XXIII's decision to convene the Council in 1962 could not have known that his call for "updating” would eventually affect scores of doctrines and practices that for hundreds of years had distinguished Catholicism from Protestantism.

The architects of Vatican II did not anticipate the consequences of their reforms. Catholicism had been growing for a hundred years or more, and the 1946-1965 post-war period had witnessed especially rapid growth: in total number of Catholics, in church attendance rates, in the numbers of priests and nuns, and in Catholic schools and hospitals. To the great surprise and dismay of Catholics everywhere (and especially the Catholic hierarchy), all these growth trends reversed immediately after Vatican II. Among the hundreds of historians, sociologists, and religious scholars who have analyzed the Vatican II era with methods ranging from textual analysis to survey research, we encounter nearly unanimous agreement that the decline was unanticipated and precipitated primarily by changes initiated by the Church hierarchy, rather than by external events or changes (such as trends in income, education, or female employment, or changes in the secular culture).

Liberals and conservatives within the Catholic Church disagree strongly over the mechanism by which Vatican II caused attrition of clergy from the Church. Liberals argue that by convening the Council the Church created an expectation of even broader reforms, which might include allowing clergy to have families and payment for their services - more in line with Protestant practice. When those expectations were dashed, goes the argument, nuns, priests brothers and prospective clergy decided that the awaited reforms would not happen in their lifetimes, and reacted by either leaving the fold or declining to join in the first place.

\footnotetext{
${ }^{4}$ Wilde (2007) provides a fascinating account of how "progressive” bishops managed to outmaneuver conservatives in order to engineer an unexpected and revolutionary change in Catholic practice.
} 
Conservatives have a very different explanation for the attrition of clergy. They claim that before the Second Vatican Council clergy were placed on a theological pedestal, recognized for their holy work. The Council, in an ecumenical expression of tolerance and inclusion, now recognized everyone performing social services such as education, care for the sick and care of the poor, as those are all valuable services. The pedestal for secular providers was not as high as that of nuns and priests, but the effect was to reduce the theological premium that clergy had over secular providers of many of the same services. So it is not surprising that nuns, brothers and priests effectively jumped pedestals, trading off a reduced theological premium against the value of having families and, for the nuns and brothers, earning wages. Whichever explanation one accepts, the conservative or the liberal, the key to what follows is that both explanations are exogenous to fertility.

Official Church statistics provide detailed evidence of institutional losses following Vatican II. These diminished the Church's labor force, undermined its capacity to provide traditional services (most notably Catholic schools, day care, and hospitals), and reduced its visible presence in community life. ${ }^{5}$ Starke and Finke (2000), using data from the Official Catholic Directory, report that the number of nuns in the U.S. rose steadily from about 140,000 in 1948 to 180,000 in 1966, the concluding year of Vatican II. Steady growth then immediately turns into precipitous decline, dropping to about 90,000 by 1995 and continuing downwards thereafter, as illustrated in Figure 2, which is reproduced from Starke and Finke (2000). Similar mid-to-late 1960s turning points have been extensively documented in the U.S., for the number of priests, average rates of mass attendance, contribution rates, and respect for Church doctrine.

Post-Vatican II declines do not follow identical paths in all countries, but in every developed Western country the number of priests and nuns began to decline dramatically within five years after 1965, as we will see below for Western Europe.

\section{Catholic Social Services}

Before Vatican II the Church played an important role in providing social services in strongly Catholic countries and communities. Nuns were instrumental in that provision. In Italy, for example, "until 1966 virtually all [pre-schools] were private [and] seventy percent of nursery and kindergarten children were cared for by religious sisters.” (Lee, et al, 1967: 165). In pre-Vatican II America, about 50\% of Catholic children attended Catholic schools in the 1950s, and Catholic hospitals provided about one-fifth of all hospital beds (while Catholics accounted for about onefourth of the U.S. population) (Fialka 2003: 3). Social life in Catholic communities routinely revolved around the Catholic parish and Catholic organizations.

The number of nuns provides the best single index of Catholic social services, since nuns have traditionally provided the primary labor supply staffing Catholic schools, hospitals, and other Church-related institutions. Table 1 reports on nuns per 10,000 Catholics in various countries in Europe, showing that the level of clergy-provided services varied widely across countries in the 1960s. (Data sources are documented in Section 5 below.) Examining the seven European countries with Catholics majorities, the number of nuns per 10,000 Catholics in 1960

\footnotetext{
${ }^{5}$ The reforms of Vatican II had the effect of further reducing the visibility of clergy. Nuns stopped wearing distinctive habits, popular but mythical saints were dropped from the official catalog, mass was no longer said in Latin, confession became optional [and hence rare], and "meatless" Fridays ceased to be required.
} 
ranged from seven in Portugal and eight in Poland to 60 in Ireland. By the year 2000 that range had narrowed considerably as the number of nuns per 10,000 declined to 32 in Ireland but remained at seven in Portugal. As a result, Irish Catholics, for instance, suffered much more clergy attrition per capita after Vatican II than did Catholics in other countries. As reflected in the rightmost column: Ireland lost 28 nuns per 10,000 Catholics, France 20, Austria 13 and Italy 11, while in Spain, Poland and Portugal, the declines were much smaller: six, one and zero respectively.

How important could these nuns have been as social service providers? For comparison, for each 10,000 people in the U.S. there are 97 teachers (pre-kindergarten through elementary), 86 nurses and 29 social workers. While the number of nuns/Catholic is less than that in these European countries, it is of the right order of magnitude, especially considering that we have not counted brothers, priests and volunteers and that a parallel secular workforce exists in these occupations.

In the U.S., extensive survey data on religious activity and religion-specific fertility stretch back to the 1940s. From the mid-1800s through the mid-1900s the Catholic population, about one quarter of Americans, remained visibly distinctive - with its own schools, characteristic ethnicities, low intermarriage to non-Catholics, and a full complement of "parallel" institutions, including churches, social clubs, business associations, civic associations, and academic societies.

The strength and size of Catholic parallel institutions in the U.S. peaked in the 1950s (Greeley, McCready, et al. 1976; Greeley 1977). By the late 1960s, most of these institutions had closed, shrunk, or became non-sectarian. A comprehensive study of religious orders found that between 1962 and 1992, orders of sisters shrank by 42\%. The orders shut down 23\% of their hospitals, $15 \%$ of their universities and colleges, and $42 \%$ of their elementary schools. By the end of the century there were fewer than 81,000 sisters in America (compared to the 1968 peak of 180,000) and their median age was sixty-nine (Fialka 2003:17). Overall, $40 \%$ of the Catholic high schools and 27\% of elementary schools closed between 1964 and 1984 . These closure rates underestimate the loss of nuns. In the schools that remained, the share of non-lay teachers rose from under $10 \%$ in the 1920 s through 1950 s to peak at $70 \%$ in the mid-1960s, but then declined to $46 \%$ in $1970,26 \%$ in $1980,12 \%$ in 1990 , and $6 \%$ in 2000 . Those most familiar with Catholic schooling data claim the decline was almost entirely induced by supply effects, as nuns left, were replaced by (much higher paid) lay teachers, and schools could no longer cover these higher staffing costs (Dolan 1992:442, Bryck and Holland 1993: 52).

Catholic church attendance and fertility in the U.S. also rose before Vatican II and fell afterwards. Catholic fertility did not merely exceed Protestant fertility during the post war "baby boom” it experienced both a magnified rise and fall (Westoff and Jones 1979). Since 1965 Catholic fertility has declined by about a child per woman more than Protestant fertility, mirroring the excess decline for Catholics in Europe (Hout and Greeley 1987; Greeley 1989). Our primary concern is to understand why. In the following section we will develop a general framework that allows us to test competing theories. 


\section{Economic Fertility and Religion: A Framework for Estimation}

To summarize the historical setting, we take it as given that the Second Vatican Council caused a sharp decline in clergy per Catholic in Europe, though the timing differed across countries, and that the decline in available clergy reduced services, both spiritual and tangible, provided to Catholic communities. The 1960s also witnessed dramatic changes in the general culture which could have affected fertility norms. This section describes competing theories and draws out their testable implications.

Several mechanisms linking religiosity to fertility are often discussed and plausible: First, religion could affect individual preferences for children or for use of birth control. Second, religion could influence social norms regarding childbearing or women's work. Third, religion could affect a mother's educational attainment and thus change the opportunity cost of raising children. Fourth, religion could affect national politics and thus the provision of child-friendly social services by government. A fifth alternative, which combines institutions and a BeckerSchultz approach, is that religious communities might reduce the effective price of raising children by providing child-friendly social services such as day care, schools, and medical care. A club model of denominations would generate a variant of that mechanism, in which families that demonstrate more religiosity obtain preferential access to services. Finally, it's possible that religiosity and theology are merely symptomatic of attitudes toward fertility that change for other reasons.

Anticipating the results, the speed of clergy attrition will refute the hypothesis that religious changes are symptomatic of general changes in popular attitudes. That will leave us to examine mechanisms by which religion causes fertility, whether through theological, educational political or service-provision channels.

\section{Religion in a Fertility Model: Preferences and Service Provision}

A theoretical framework helps clarify how religion might affect fertility. Assume a family maximizing a joint utility function for two adults and $f$ children by optimally choosing consumption, $C$, and the number of children $f^{67}$,

\section{(1) $\underset{c, f}{\operatorname{Max}} U(c, f, \mu)$, where}

Here the family is concerned with consumption per family member $c=\frac{C}{2+f}$, in the tradition of a Becker (1991) quality-quantity model. ${ }^{8}$ It also gains direct utility from fertility.

We also allow the possibility that fertility norms enter a family's utility, using a formulation from research on identity (Akerlof and Kranton, 2000, 2010), in which the family

\footnotetext{
${ }^{6}$ For our purposes this could also be a single-parent family in which choices are made by the mother.

${ }^{7}$ Adding leisure as a use of time will not alter the main results, under the homotheticity assumption we invoke below.

${ }^{8}$ This formulation differs from Becker's (1991) demand for children in three ways: first, goods are per-capitized over all family members, not only children; second, the use of goods per capita is not necessarily interpreted as investment -analytically this makes no difference in a static model; third, we introduce (in (2)) a time-cost of childrearing as in Gronau (1977).
} 
experiences disutility associated with the distance between actual fertility, $f$, and some theological (or ideological) constant, $\mu$, representing norms of desired fertility. ${ }^{9}$ In that term, $\pi$ is the weight associated with a religious identity, which is influenced by religiosity, $a$. This term could also be understood as reflecting the disutility associated with the use of birth control, to the extent that it affects fertility, the outcome of interest.

Denoting derivatives with subscripts, we assume that $\mathrm{u}_{1}, \mathrm{u}_{2}$ and $\pi_{\mathrm{a}}$ are positive, that $\mathrm{u}_{11}$, and $\mathrm{u}_{22}$ are non-negative, that fertility and consumption per capita are weak complements, $\mathrm{u}_{12} \geq 0$, and that both increasing in all their arguments, that $\mathrm{u}\left(\right.$.) is concave, and that $\mathrm{u}_{1}(0)=\mathrm{u}_{2}(0)=\infty$.

The family is subject to a budget constraint where a fixed time allocation, $T$, can be spent either on work hours, $H$, or raising children $\lambda f$,

$$
\text { (2) } C=w H=w(T-\lambda f) \text {. }
$$

In terms of consumption per capita, the budget constraint is

$$
\text { (2') } \quad c=\frac{w H}{2+f}=\frac{w(T-\lambda f)}{2+f} .
$$

Religion can enter this budget constraint in three ways. Let $q$ measure the quality of social services provided by church, and assume that both $q$ and $a$ affect the time cost of raising children $\lambda=\lambda(a, q)$. The idea is that low cost schooling, daycare and health services reduce the time required of parents in raising children. One mechanism is through service quality. As service quality improves (through longer hours or more attractive church-provided services) then the time cost of childrearing would decline in quality, $\frac{d \lambda}{d q}<0$. A variant of that mechanism would be political, with churches successfully lobbying for public policy changes that lower the cost of childrearing. A second effect of religion is through access. If access to social services is preferentially provided to individuals who publicly display religiosity through religiosity, then $\frac{d \lambda}{d a}<0$ when $q>0$, and $\frac{\partial^{2} \lambda}{\partial a \partial q}<0$. Conditioning service provision on religiosity by a religious institution is rationalized by a club model (Iannaccone 1992, Berman, 2000). A third channel runs through wages. Religious norms and prohibitions tend to reduce the effective wage of women by restricting their access to labor markets and their productivity when working (as in Berman (2000) and Berman and Stepanyan (2003)), so that $w=w(a)$, with $\frac{d w}{d a}<0$.

We solve for the optimal choice of consumption and fertility to derive a demand for fertility. That optimum is illustrated by point A in Figure 3. Note that the budget constraint (2') is

\footnotetext{
${ }^{9}$ A more general specification might include leisure. That generalization would not affect the derived estimating equations or the analysis that follows.
} 
downward sloping and convex: $\frac{\partial c}{\partial f}=\frac{-\lambda w(2+f)-w[T-\lambda f]}{(2+f)^{2}}<0 ; \frac{\partial c}{\partial f}=\frac{-w[2 \lambda+T]}{(2+f)^{2}}$ so $\frac{\partial^{2} c}{\partial f^{2}}=$ $\frac{2 w[2 \lambda+T]}{(2+f)^{3}}>0.10$

Substituting (2') in (1) yields

$$
\operatorname{Max}_{f} u\left(\frac{w(T-\lambda f)}{2+f}, f\right)-\pi(a)(f-\mu) 1(f<\mu) .
$$

The first order condition is then

$$
0 \geq \frac{\partial U}{\partial f}=-u_{1} \frac{w(2 \lambda+T)}{(2+f)^{2}}+u_{2}+\pi(a) 1(f<\mu)
$$

The infinite marginal utility assumptions rule out solutions at $f=0$ or $c=0,(f=T / \lambda)$, so that the derivative condition above holds with equality except possibly for a solution where $f=\mu$, the kink in the indifference curve in the Figure.

The second order condition assures that the optimum illustrated at $\mathrm{A}$ is a unique maximum for $f \neq \mu$,

$$
\frac{\partial^{2} U}{\partial f^{2}}=u_{11}\left[\frac{w(2 \lambda+T)}{(2+f)^{2}}\right]^{2}-u_{12} \frac{w(2 \lambda+T)}{(2+f)^{2}}-u_{1} \frac{2 w(2 \lambda+T)}{(2+f)^{3}}+u_{22}<0 .
$$

Intuitively, this is the result of the indifference curve being more convex than the budget constraint.

Solving for the optimal choice of consumption and fertility yields a derived demand for children in terms of wages, the weight placed on norms of fertility, and the cost of raising children,

$$
\text { (3) } \quad f(w(a), \pi(a), \lambda(a, q)) \text {. }
$$

Proposition: Fertility increases in the weight on norms $(\pi)$ when $f<\mu$ and decreases in childrearing costs $(\lambda)$ when $f \neq \mu$.

Proof: Applying the Implicit Function Theorem,

$\frac{d f}{d \pi}=-\frac{\partial^{2} U}{\partial f \partial \pi} / \frac{\partial^{2} U}{\partial f^{2}}=-1(f<\mu) / \frac{\partial^{2} U}{\partial f^{2}}>0$.

${ }^{10}$ An aspect of the quality-quantity model not emphasized by Becker's discussion is that increased childrearing costs increase the convexity of the budget constraint: $\frac{\partial^{3} c}{\partial \lambda f^{2}}=\frac{4 w}{(2+f)^{3}}>0$, making multiple equilibria more likely. That increase in convexity, in turn results from increases in childrearing costs reducing resources more for high fertility families. In the figure, increased $\lambda$ squeezes the budget constraint in along the horizontal axis by reducing available time while its' intercept remains unchanged in terms of available consumption. (Increased wages also increase convexity in Becker's treatment of the question.) 
$\frac{d f}{d \lambda}=-\frac{\partial^{2} U}{\partial f \partial \lambda} / \frac{\partial^{2} U}{\partial f^{2}}, \frac{\partial^{2} U}{\partial f \partial \lambda}=-u_{11} \frac{-w f}{2+f} \frac{w(2 \lambda+T)}{(2+f)^{2}}-u_{1} \frac{2 w}{(2+f)^{2}}+u_{22}<0$ so $\frac{d f}{d \lambda}<0$.

Figure 3 illustrates this fertility effect of raising childrearing costs, which shifts the budget constraint inward, reducing full income and raising the opportunity cost of each child. The new equilibrium is illustrated at point B. Note that while fertility is unambiguously reduced, the effect on consumption is ambiguous. Likewise, the effect of increased wages on fertility is ambiguous because wages have both income and substitution effects, though the literature has emphasized the substitution effect (Becker and Lewis, 1973)), operating through the opportunity cost of a mother's time.

We do not observe $w, \lambda$, or $\pi$, but we can restate the demand for children in terms of religiosity, $a$, and quality of services, $q$, for which we observe proxies. A reduced form in terms of $a, q$, and an interaction (explained below) is $f^{*}$

$$
f(w(a), \pi(a), \lambda(a, q))=f^{*}(a, q)
$$

This equation implies three interesting predictions about how religiosity and service provision affect fertility. First, examining the terms reveals that fertility likely increases in religiosity $a$, through each of three mechanisms:

$$
\text { (4.1) } \frac{d f}{d a}\left|q=\frac{\partial f}{\partial w} \frac{d w}{d a}+\frac{\partial f}{\partial \pi} \frac{d \pi}{d a}+\frac{\partial f}{\partial \lambda} \frac{d \lambda}{d a}\right| q
$$

Starting with the rightmost term, if service provision is conditional on demonstrating religiosity, so that religiosity provides preferential access to lower cost childrearing services, as we argued above that a religious club would do, then $\frac{d \lambda}{d a}<0$. Since childrearing costs lower fertility (see the proposition), the rightmost term is positive. The middle term is also positive if high religiosity increases the influence of norms or theology, $\pi$, on a woman's fertility behavior, since $\frac{\partial f}{\partial \pi}$ is positive (by the proposition). The first term on the right measures the effect of religiosity on fertility through labor markets. If religiosity shifts a woman's norms away from a lifestyle that encourages human capital formation and active labor force participation, we can think of that as religiosity lowering market wages, $\frac{d w}{d a}<0$. That term has ambiguous sign since the sign of $\frac{d f}{d w}$ depends on whether a positive income effect of increased wages is dominated by a negative substitution effect (analogous to a possibly backward-bending labor supply curve). Empirically, the literature has found a dominant substitution effect, so that $\frac{d f}{d w}<0$, leading us to cautiously predict an overall positive effect of religiosity on fertility in (4.1). We have the ability to estimate $\frac{d f}{d a} \mid q$ holding labor force participation constant, allowing us to isolate the two rightmost terms representing norms and the cost of raising children, which are unambiguously positive. 
A second prediction is that service quality, $q$, unambiguously increases fertility by lowering the cost of childrearing. Note that this effect is entirely through the budget constraint -not through preferences.

$$
\text { (4.2) } \frac{d f}{d q} \mid a=\frac{\partial f}{\partial \lambda} \frac{d \lambda}{d q}>0 \text {. }
$$

Third, if access to social services is preferentially provided to individuals displaying at least some religiosity, $a$, as a club would do, then social service quality and religiosity will be complements in fertility,

$$
\text { (4.3) } \frac{\partial^{2} f}{\partial a \partial q}=\frac{\partial f}{\partial \lambda} \frac{\partial^{2} \lambda}{\partial a \partial q}>0 \text {. }
$$

To test those predictions, we will measure religiosity, $a$, using church attendance present and past--, allowing us to link observable religiosity to fertility. We will use nuns per Catholic as our measure of $q$, recalling that nuns provided much of the staffing of educational, health, and welfare services during the heyday of Catholic social service provision. We turn now to a description of data that will allow us to test these predictions.

\section{Data}

We make use of data from three sources: administrative data from the Vatican, the International Social Survey Program (ISSP) and the World Development Indicators (WDI).

The Vatican collects data for each diocese in the world, including the number of priests (diocesan and regular), nuns, churches, schools, hospitals, other institutions, Catholics and new baptisms. These data are available dating back to 1959 on an annual basis. ${ }^{11}$ Figure 4 reproduces a page from the 1960 Annuario Ponteficio describing entries for Agra in India and Agrigento in Sicily (the birthplace of one of the authors).

The ISSP provides standard household survey data comparable across countries (31 in the 1998 wave). ${ }^{12}$ Critically, it includes a retrospective question on the religious participation of the respondents and their parents. The question asks "[W]hen you were around 11 or 12, how often did you/your parents attend religious service?” We use that as a measure of religiosity.

The ISSP is also our source for church attendance rates. Church attendance trends are those calculated by Iannaccone (2002) using the same retrospective questions we used to build the religiosity measure. Using the 1991 and 1998 wave of the ISSP-the only two waves to ask the retrospective questions- Iannaconne builds a time series of church attendance rates for the 31 countries sampled by the ISSP. That time series covers the 1940s through the 1990s. By careful

\footnotetext{
${ }^{11}$ Unfortunately, the Annuario Ponteficio, dating back to 1959, reports data only at the disaggregated diocesan level, without regional or national aggregation. In 1970 the Vatican began publishing aggregates in the Annuarium Statisticum Ecclesiae.

${ }^{12}$ For details see www.issp.org .
} 
analysis and crossvalidation, Iannaccone (2002) finds that the patterns of attendance built from the retrospective questions are reliable and remarkably consistent.

From the WDI we obtain Total Fertility Rates, population, education and female labor force participation. ${ }^{13}$

\section{Estimation}

Before turning to estimates, a preliminary look at these data are instructive. Figure 5 reports on the absolute number of nuns in France, Germany, Italy and Spain between 1960 and 2000, illustrating that the European pattern of attrition after Vatican II mimics that described in the literature for the U.S. In Italy and Germany the number clearly peaks in 1965, the last year of Vatican II, then declines sharply afterwards. France shows a peak in nuns in 1960 after a previous increase (not shown) and a sharp decline following 1965. In Spain, rapid growth through 1965 is followed by deceleration and then decline after 1970.

Figure 6 reports on both nuns per capita and fertility per capita for Ireland, foreshadowing the estimation results below. Ireland shows a clear peak in nuns per capita in 1965 (mirroring Italy and Germany in the previous figure), which corresponds to a peak in total fertility rates (shown in the right panel).

Note how rapid the onset of clergy attrition is in Italy, Spain, Germany and Ireland, changing from persistent growth to rapid decline between 1965 and 1970 (Figures 5 and 6). We see this as evidence that Vatican II had an immediate effect, over and above any broad trend in the general culture's attitude towards clergy.

Figure 7 reports on church attendance rates, our measure of religiosity, for the same three categories of countries reported in Figure 1 of the introduction, between 1960 and 1990. Note that all European countries have experienced declines in church attendance (and in other indicators of religiosity -not shown). While attendance fell by over twenty percentage points in the Protestant countries, the decline in the Catholic countries was only ten percentage points over that 30 year period. Explanations for declining Catholic fertility, relative to that of Protestants, must come from some mechanism other than declining religiosity.

\section{Estimating Equation}

We begin by constructing an estimating equation for the demand for fertility derived in Section 4, then aggregate it to correspond to the country level data we observe.

For an individual woman, $i$, we posit a linear version of (4), the demand for fertility,

\footnotetext{
${ }^{13}$ To validate WDI fertility figures we also used the ISSP to obtain an approximate measure of completed fertility, using a series of questions about the number of children living in the household. To assess its quality, we compared the ISSP fertility measure with that from obtained by using data from the 1998 wave of the Survey of Italian Households' Income (SIHIW) run by Bank of Italy. The ISSP reported 1.31 children at home whereas the SIHIW reported 1.29 children, both of which are very close to the Italian TFR of 1.19 in 1998 . The two surveys also give very similar results in a regression of children on years of education and other personal characteristics, suggesting that the fertility measure and the ISSP sample altogether are remarkably consistent.)
} 


$$
f_{i t}=\alpha_{s}+\beta^{r} a_{i t}+\theta^{r} q_{s t}+\gamma^{r} a_{i t} q_{s t}^{r}+\delta_{t}+\eta_{i t}
$$

where the superscript $r$ and the subscript $s$ index religious groups, in our case Catholics and nonCatholics: $r \epsilon(C, N C)$. , $s \in(C, N C)$. Attendance is an individual characteristic, while quality of service provision is common to coreligionists.

Restating the predictions of our framework in terms of estimated coefficients for Catholics, we have three items of interest. The attendance effect on fertility includes the effect of religiosity through opportunity costs, the effect of religiosity through norms, and the effect of religiosity through preferentially reduced costs of raising children for church attendees. We posit that it is positive, assuming that substitution effects dominate income effects in the wage term.

$$
\text { (4.1) } \frac{d f}{d a} \mid q=\frac{\partial f}{\partial w} \frac{d w}{d a}+\frac{\partial f}{\partial \pi} \frac{d \pi}{d a}+\frac{\partial f}{\partial \lambda} \frac{d \lambda}{d a}=\beta^{r}+\gamma_{q}>0 \text {. }
$$

The nuns per capita effect on fertility includes both neutral reduced costs of raising children for nonattendees, and the preferentially reduced costs for attendees,

$$
\text { (4.2) } \frac{d f}{d q} \mid a=\frac{\partial f}{\partial \lambda} \frac{d \lambda}{d q}=\theta^{r}+\gamma^{r} a>0 \text {. }
$$

The interaction coefficient, which captures the fertility increase due to preferentially reduced costs of raising children for attendees,

$$
\text { (4.3) } \frac{\partial^{2} f}{\partial a \partial q}=\frac{\partial f}{\partial \lambda} \frac{\partial^{2} \lambda}{\partial a \partial q}=\gamma>0 \text {. }
$$

We seek estimates of $\beta^{C}, \gamma^{C}$ and $\theta^{C}$, which will capture, respectively, the effects of norms and theology, service provision, and preferential service provision for attendees.

Aggregating (5) for Catholics in a particular country, c, is straightforward,

$$
f_{C c t}=\alpha_{C c}+\beta^{C} a_{C c t}+\theta^{C} q_{C c t}+\gamma^{C} a_{C c t} q_{C c t}+\delta_{t}+\eta_{C c t} .
$$

Turning now to measurement, our proxy for religiosity, $a$, is church attendance rates, as is standard in the literature. Social service provision for Catholics is, $q_{C}$, is proxied by nuns per Catholic, recalling the discussion above of the critical role that nuns played in staffing hospitals day care centers, schools and welfare services.

Unfortunately, we lack estimated fertility rates for Catholics by country, and the ISSP does not provide precise estimates of church attendance rates for Catholics separately, forcing us to use aggregate fertility as a left hand side variable and to approximate religion specific church attendance rates with national church attendance rates.

National fertility rates can be expressed as the weighted average of Catholic and NonCatholic specific rates, where $P_{c}$ is the Catholic proportion of the population (this proportion is well approximated as time-invariant during the relevant period), i.e., $f_{c t}=P_{c} f_{C c t}+\left(1-P_{c}\right) f_{N C c t}$. 
Substituting in (5') and the equivalent equation for non-Catholics yields

$$
\begin{aligned}
& f_{c t}=P_{c}\left[\alpha_{C c}+\beta^{C} a_{C c t}+\theta^{C} q_{C c t}+\gamma a_{C c t} q_{C c t}+\delta_{t}+\eta_{C c t}\right] \\
& \quad+\left(1-P_{c}\right)\left[\alpha_{N C c}+\beta^{N C} a_{N C c t}+\theta^{N C} q_{N C c t}+\gamma^{N C} a_{N C c t} q_{N C c t}+\delta_{t}+\eta_{N C c t}\right] .
\end{aligned}
$$

Assuming $a_{c t}^{C}=a_{c t}^{N C}=a_{c t}$, and substituting, we get

$$
f_{c t}=\alpha_{c}+\beta^{N C} a_{c t}+\left(\beta^{N C}-\beta^{C}\right) P_{c} a_{c t}+\theta^{C} P_{c} q_{C c t}+\gamma^{C} a_{c t} P_{c} q_{C c t}+\delta_{t}+\varepsilon_{c t},
$$

where all the time-invariant terms are captured in a country effect $\alpha_{c}=P_{c} \alpha_{C c}+\left(1-P_{c}\right) \alpha_{N C c}$, and the error term includes all terms involving unmeasured quality of non-Catholic social services, $\varepsilon_{c t}=\left(1-P_{c}\right)\left[\theta^{N C} q_{N C c t}+\gamma^{N C} a_{N C c t} q_{N C c t}\right]+\eta_{C c t}+\eta_{N C c t}$. These omitted variables will cause a bias in a fixed effects specification only if the changes in family-friendly services available to non-Catholics are correlated with changes in the number of nuns per Catholic. equation to

Denoting nuns per capita as $n_{c t}$ and noting that $n_{c t}=P_{c} q_{C c t}$, we simplify our estimating

$$
f_{c t}=\alpha_{c}+\beta^{N C} a_{c t}+\left(\beta^{C}-\beta^{N C}\right) P_{c} a_{c t}+\theta^{C} n_{c t}+\gamma^{C} a_{c t} n_{c t}+\delta_{t}+\varepsilon_{c t} .
$$

We estimate in differences over five years intervals. Differencing allows for nonstationarity in the error $\left(\varepsilon_{c t}\right)$. A five year interval is chosen rather than a single year interval in order to reduce year to year measurement error in church attendance. So our estimating equations are of the form

$$
\begin{gathered}
\Delta f_{c t}=\beta^{N C} \Delta a_{c t}+\left(\beta^{C}-\beta^{N C}\right) \Delta P_{c} a_{c t}+\theta^{C} \Delta n_{c t}+\gamma^{C} \Delta a_{c t} n_{c t}+\Delta \delta_{t}+\Delta \varepsilon_{c t}, \\
\text { where } \Delta \mathrm{x}_{\mathrm{t}} \equiv \mathrm{x}_{\mathrm{t}}-\mathrm{x}_{\mathrm{t}-5} \text { for any variable } \mathrm{x} .
\end{gathered}
$$

\section{Estimates}

Table 2 contains summary statistics for the variables included in equation (6), with means reported in five year differences. Total fertility declined by an average of 0.14 children per woman over each five year interval from 1960 through 2000, a cumulative decline of 1.12 lifetime children. Nuns per capita, church attendance and their interaction all showed declines, but with considerable variation across countries.

Table 3 reports estimated effects of religiosity and service provision (partial derivates (4.1) and (4.2)) for a panel of 14 European countries between 1960 and 2000. Religiosity alone, as proxied by current church attendance, does not significantly predict fertility, when we pool across countries with different mixes of Catholics and Protestants, as reported in column (1). That result changes when we allow a separate coefficient for Catholics, which yields a statistically significant point estimate of 0.02 (column (2)). That's a large estimate, suggesting that in a (hypothetical) entirely Catholic country, a ten percentage point decline in church attendance predicts a TFR reduction of 0.2 children. That result is not altered by including a measure of female labor force participation (column (3)), which suggests that the effect of religiosity through raising opportunity costs of work is negligible. 
Referring back to equation (4.1) in the framework section, estimates in these first three columns provide strong evidence against any effect of religiosity on fertility for Protestants, either through norms and theology $\left(\frac{\partial f}{\partial \pi}\right)$ or through service provision and the cost of raising children $\left(\frac{\partial f}{\partial \lambda}\right)$. For Catholics, on the other hand, the sum of those effects is large and positive, though the analysis does not allow us to distinguish between mechanisms. That difference between the estimated effects for Protestants and Catholics is therefore consistent with either stronger pronatalist norms among Catholics or stronger service provision among Catholics, or both.

One caveat is the possibility of reverse causality: church attendance might be affected by fertility if parents attend church because they feel it benefits their children ${ }^{14}$. In the discussion of reduced church attendance post Vatican II, the possibility that it occurred because there were less children is not mentioned in the literature. Moreover, it would be hard to explain why that mechanism appears for Catholics but not for Protestants, who experienced a trend reduction in church attendance without

What about service provision? The right three columns of the table report estimates of the derivative in (4.2), showing very strong evidence of an effect of service provision (as proxied by nuns/capita) on fertility. Each nun per capita yields a large and statistically significant coefficient ranging from 383 to 408 children, a result that is robust across specifications. These coefficients can be interpreted as children per nun since both fertility and nuns per capita are normalized by population. Of course these are only estimates and should be treated with caution. The standard error on the children per nun estimate in column (4) is 124 children. Nevertheless, the magnitude is remarkably large if we were to hazard a causal interpretation (more on that below). Apparently the vows that nuns took not to bear their own children are more than compensated for by their effect on the fertility of others!

Before proceeding, a comment on statistical inference is necessary. Calculating standard errors and statistical significance is complicated by the small number of countries in the sample (14) so that asymptotic approximations rely on the NxT rather than N. We report standard errors clustered by country over time, corrected for the possibility of poor asymptotic approximation of a normal distribution by the jacknife-equivalent procedure proposed by Bell and McCaffrey (2002), which corresponds to the "CR3" standard errors of Cameron, Gelbach, and Miller (2008). Critical values used to denote statistical significance are those of a tdistribution with thirteen (the number of countries minus one) degrees of freedom. We have validated the statistical significance of these results using the alternative "wild bootstrap" procedure of Cameron, Gelbach and Miller (2008), which is designed to treat the same smallsample problem, but has lower power. Rejection probabilities (p-values) using that procedure are quite similar in general. (The two cases in which they differ are noted in footnotes below.)

\footnotetext{
${ }^{14}$ The ISSP data provides an excellent resource to further test for this endogeneity bias, because it provides retrospective church attendance data dating back many years. A lag would allow some time for religious human capital accumulation, religious social capital accumulation, and fertility preference formation by individuals so that fertility in the childbearing years can be influenced by attendance in childhood. The same regression using church attendance (as children) with 10 or 15 year lags also yields statistically insignificant coefficients (Table 4). The results are also robust to adding years of education for women aged 15+ (from the Barro-Lee data) as an alternative measure of the economic opportunities of women. The estimated coefficient is positive but insignificant.
} 
Again, we might have some concern with reverse causality, if one thought that the number of nuns responds to the demand for service provision, which is in turn tied to fertility. The literature on clergy attrition post Vatican II nowhere mentions this possibility, nor can we think of a mechanism by which clergy recruitment or attrition responds that quickly to demand; clergy typically join for life and leave for personal or theological reasons. Finally, examining Figures 5 and 6, we can't think of a mechanism that would reduce fertility so suddenly and differentially in France, Germany, Italy, and Ireland starting in 1965, and in Spain starting in 1970, to drive the posited reverse causality mechanism.

Our argument for identification of the coefficient on nuns/capita rests on the assertion that the decline in nuns per capita after 1965 was initiated by the exogenous shock of Vatican II, generating differential declines in different countries, which for historical reasons had variations in the levels of nuns per Catholic. The data that most closely captures the effects of that shock is from the 1960s and 1970s, so as a robustness check, we re-estimated for that subsample of the data, to be sure that the results match those in Table III. Those results are reported in Appendix Tables A.1 and A.2, which show that the coefficient on nuns/capita remains large and statistically different from zero for the 1960-1980 sample, while for the shorter 1960-1975 sample the point estimate remains about the same but the larger standard errors preclude drawing statistical inference. (As in Table 3, standard errors are calculated using theBell and McCaffrey (2002) method.)

Having established that both attendance and service provision predict increased fertility, we now turn to attempting to distinguish between mechanisms by estimating equation (6), which includes an interaction term. The positive religiosity effect $\left(\beta^{C}+\gamma^{C} q\right)$ could be due to either norms $\beta^{C}$ or conditional service provision, $\gamma^{C} q$ (recalling that the opportunity cost term in (4.1) had been removed by conditioning on labor force participation). The pronatalist service provision effect $\left(\theta^{C}+\gamma^{C} a\right)$ could be either unconditional, $\theta^{C}$, or conditional, $\gamma^{\gamma}$.

Table 4 reports on our attempts to test the conjecture of conditional service provision by estimating equation (6), which includes as a regressor the interaction of nuns/capita with our estimate of Catholic attendance. The theory of conditional service provision provides no guidance as to when in one's life a member of a congregation signals religiosity in order to gain access to services. Is it current religiosity that matters for a mother, or perhaps religiosity signaled at the age of communion, or in between? We remain agnostic on this point and report interactions of nuns/capita with current attendance, attendance lagged ten years, and attendance lagged fifteen years. The first column repeats the specification in Table (3) for comparison (383 children per nun). Columns (2) through (4) report that we unfortunately lack sufficient precision to estimate both a service provision coefficient, $\theta^{C}$, and an interaction, $\gamma^{C}$ when using current attendance as our measure of religiosity. While the interaction terms persistently have positive signs, suggesting conditional service provision, none of the three are statistically different from zero. Unfortunately, in this specification the "main" effects of service provision and religiosity also yield statistical zeros as estimates, so that nothing can be learned.

Further inference requires a compromise. Estimates of attendance are available only through 1990, so that dropping current attendance rates from the regression allows two more five 
year periods to be added to the estimation panel, 1990-95 and 1995-2000. If we drop the current attendance term from the regression, replacing it with lagged attendance, then we can gain some precision in estimating the interaction coefficient. That exercise is pursued in columns (5) through (7), using the full sample of five-year differences between 1960 and 2000 (eight differences $x$ thirteen countries for a total of 104 observations). Column (5) reports the baseline regression for the full panel, reporting a statistically significant coefficient on nuns/capita of 296 children per nun. That estimate is a little smaller than the estimates in Table 3 using the shorter sample period, but not statistically different.

The next column reports coefficients on nuns per capita, attendance lagged ten years, and the interaction of nuns/capita and lagged attendance. In this case the interaction has a large and statistically significant coefficient of 17.7. The main effect of nuns per capita is large and negative ${ }^{15}$, and that of attendance is also statistically negative. To put the interaction coefficient in context, at an attendance rate of $82 \%$ (the Catholic average in 1960), each nun would account for $(82 x 17.7-1032)=419$ children, which is consistent with previous estimates.

At the fifteen year lag the interaction term is also statistically significant, at 10.8, though the two main effects (nuns and attendance) are not. We conclude that service provision may well have been conditional on attendance, as the evidence from the longer sample period indicates. ${ }^{16}$ If we concentrate on that longer sample period, mindful of the compromise of dropping the current attendance term, the negative estimated coefficient on nuns per capita in columns (6) and (7) provide evidence against a positive unconditional fertility effect of service provision, forcing us to conclude that $\theta^{C}=0$ in (4.2).

While this table provides no evidence to refute the conjecture of an effect of norms or theology on fertility, a parsimonious explanation for all the results would simply be that service provision is both fertility increasing and conditional on observed religiosity, i.e., that $\gamma^{C}>0$ in (4.3).

An alternative way of looking at these results is to ask how much of unexplained decline in European fertility a decline in Catholic service provision can account for. Column (8) of Table 4 reports on the explanatory power of female labor force participation, which is a well established predictor of reduced fertility. The constant in that regression predicts a decline in fertility of -0.101 per five year period once increased labor force participation by women is accounted for, or an unexplained reduction of 0.808 lifetime children over the eight five-year intervals between 1960 and 2000. These figures can only provide a rough estimate, as the constants in these regressions are not precisely estimated, but comparing the constant in column (5) to that in column (8) indicates that about 30 percent of that unexplained reduction [(0.101$0.071) / 0.101]$, or 0.24 predicted children per woman, is accounted for by reduced service provision by the Catholic Church. Given the likely attenuation bias in our estimates -due to

\footnotetext{
${ }^{15}$ The null hypothesis that the coefficient on nuns/capita (estimated as -1032) is zero is rejected at 5\% using CR3, but has a p value of only 0.098 using the “wild bootstrap.” See Cameron, Gelbach and Miller (2008) for details.

${ }^{16}$ As before, these results are virtually unchanged by removing female labor force participation from the right hand side, suggesting that the religious norms and prohibitions mechanism operating through effective wages (in the model outlined above) is relatively unimportant.
} 
noisy measures of the change in nuns/Catholic, that predicted fertility reduction due to a decline in service provision may well be an underestimate.

Are these results heavily influenced by particular countries? Figure 8 illustrates scatterplots of changes in fertility against changes in the key variable, nuns/capita interacted with lagged church attendance, with a regression line reporting the slope of the coefficient on nun/capita in Table 3, column (6). (These are "leverage" plots from the Frisch-Waugh regression). The figure labels observations by the final year of the five year difference, showing that the variation driving the regression is indeed that which occurred in the period immediately after the Second Vatican Council, from 1965-70 and from 1970-75. Figure 9 illustrates the same data, with the observations labeled by country, showing that while Ireland is important, Spain, Portugal and the Netherlands also contribute to the positive coefficient. As a further check on the importance of particular countries we have rerun the regressions omitting one country each time, and found that the results are essentially the same. (The regression coefficient on nuns/capita omitting Ireland is $365(\mathrm{p}=0.01)$.

A key assumption in our model is that nuns proxy for social service provision rather than influencing preferences for fertility through theological service provision. That assumption is difficult to test directly and cannot be literally true. An alternative way to gauge the relative importance of theological versus social services is to compare the influence on fertility of priests, as opposed to nuns. The division of labor in Catholic communities is such that a disproportionate amount of theological services are provided by priests, while most social services are provided by nuns. Attrition of priests and attrition of nuns since the Second Vatican Council is highly correlated, but not perfectly so, allowing the possibility of estimating separate coefficients for priest/capita and nuns/capita, in (4.2).

Table 5 reports the results of that exercise. Column (1) starts with the baseline specification from Table 3. Column (2) shows the same specification with priests per capita replacing nuns per capita. The coefficient is positive, like that for nuns, but very imprecisely estimated. The positive coefficient is not surprising as the correlation of these two variables is quite high, so priests could easily proxy for the omitted variable "nuns." A third specification runs a "horserace," estimating the partial regression coefficient of priests/capita with nuns/capita included in the equation. The coefficient on the nuns is large (508 children), and positive, but not statistically significant, while that on priests is negative and also statistically insignificant. Columns (4) through (6) of the Table repeat these specifications, but make use of the entire sample of observations through 2000 by dropping the current attendance rate variable (which is available only through 1990), as in Table $4 .{ }^{17}$ The results remain qualitatively the same: nuns strongly predict fertility while priests do not, though the coefficient on priests is very imprecisely estimated. In column (3) the nun and priest coefficients are not statistically different, while in column (6) they are at $\mathrm{p}<.1 .^{18}$ These results are not conclusive but again suggest that the social service provision mechanism is more important than the theological mechanism in affecting fertility.

\footnotetext{
17 The null hypothesis that the coefficient on nuns/capita (estimated as -1032) is zero rejected at 10\% using CR3, but has a p value of only 0.13 using the “wild bootstrap.” See Cameron, Gelbach and Miller (2008) for details.

${ }^{18}$ A test for equal coefficients in column (6) yields a p value of 0.61 using CR3 and 0.49 using the wild bootstrap.
} 
The results in Table 5 also provide evidence against the political mechanism conjectured in Section 4. It seems unlikely that nuns are more effective than priests in lobbying for increased public spending on low cost childrearing programs.

\section{Is the estimate too large?}

Four hundred children per nun appears to be an unreasonably large estimate, on the face of it. We provide two possible explanations, one from the theory of fertility transitions and another from an organizational theory of religious institutions.

Consider a Becker (1991) style quality-quantity model, which is designed to explain rapid fertility transitions. A natural way to illustrate the logic is to augment the household budget constraint in section 4 above by adding home production, as in Gronau (1977). For instance, meals could be cooked at home rather than purchased, or household maintenance could be selfprovided with home work hours rather than subcontracted to hired help. Assume a home production function $g\left(H_{h}\right)$ which is increasing and concave, and that work hours are now split between two home and market categories, $H=H_{h}+H_{m}$. This extension is solved by maximization in stages: the household first chooses how much to work at home by setting market wages equal to the marginal product of the last hour of home work, $w=g^{\prime}\left(\mathrm{H}_{\mathrm{h}}{ }^{*}\right)$, to define the optimal budget constraint (should $T>H_{h}{ }^{*}$, otherwise $H_{m}=0$ ). In the second stage the household optimally chooses consumption and fertility, as in Section 4 above.

Figure 10 illustrates the resulting budget constraint, which has a concave portion at the lower right, reflecting home production, and a convex portion at the upper left due to percapitization of consumption. As the Figure illustrates, this budget constraint admits multiple equilibria, at both A and B on the same indifference curve, since it has a range between those two points in which the marginal cost of an additional child in foregone consumption per capita (quality) decreases. Though they share the same utility level, families at A and B enjoy very different lifestyles, with the mother in A choosing low fertility and work in the market, while the mother in B chooses high fertility and work at home.

The Figure provides a clear illustration of Becker's approach to fertility transition. As wages increase, the budget constraint stretches vertically to higher intercept along the y-axis, allowing higher consumption to working mothers. As that process continues, should children not be a luxury good, at some high wage all optima B for working mother would be dominated.

Now consider the effect of increasing the time costs of childrearing, $\lambda$, for families in the midst of a fertility transition, indifferent between equilibria at A and B. The utility cost of increasing $\lambda$ at $\mathrm{B}$ are much higher than those at $\mathrm{A}$, since they apply to more children. Both families would respond by shifting to the unique optimum at $\mathrm{C}$, at low fertility. The formerly high fertility family shifting from $\mathrm{B}$ to $\mathrm{C}$ would experience a sharp decline in fertility due to a very small change in the cost of raising children.

In summary, a society experiencing the fertility transition as modeled by Becker would have a high proportion of families close to indifferent between high and low fertility lifestyles. For those families, small changes in childrearing costs due to the removal of the subsidy that nuns provided could have triggered a sharp reduction in fertility. 
An alternative explanation for the large fertility decline might come from the important role nuns played managing, as well as staffing, faith-based social service provision. These institutions typically include a permanent staff of clergy, often supervising lay employees and volunteers. The sudden loss of these experienced managers might have sharply reduced the quality of services provided by schools, health care facilities and other social service providers. We think of this as a complementary explanation.

\section{Discussion}

The data clearly support the service provision mechanism of European fertility decline. Declining religiosity may play a role, though only for Catholics, and even so the evidence for a religiosity effect might alternatively be interpreted as evidence that family-friendly social services were preferentially provided to families demonstrating religiosity.

The evidence for preferential service provision is strong in the 40 year sample, though not statistically significant in the shorter sample. It does provide a parsimonious explanation for all the results. Referring back to the literature, a decline in Catholic service provision, preferentially provided to church attendees, is also capable of explaining the anomaly reported by Adsera (2004) for Spain, where religiosity is uncorrelated with fertility, perhaps because the level of nuns/catholic has always been relatively low. That interaction effect might also explain the why Westoff and Jones (1979) find that communion and fertility are positively correlated in the 1950s and 1960s for U.S. Catholics, but not in the 1970s, by which time inexpensive service provision by the Catholic Church had declined in the U.S. (Stark and Finke 2000). Taken together, it seems likely not only that family friendly Catholic services were fertility enhancing, but also that these services were preferentially provided to families of churchgoers, creating an attendance-fertility correlation.

\section{Conclusions}

We have proposed a novel resolution to the Southern European fertility puzzle - the unprecedented and rapid transition to low fertility despite low female labor force participation. Our review of past research on social service provision in communal religions and our empirical results indicate that declining social service provision by the Catholic Church since the Second Vatican Council induced substantial decline in fertility among European Catholics. Declining religiosity also predicts fertility decline -though only among Catholics. That pattern seems to be particularly strong when church social service provision was extensive, suggesting that religiosity (i.e., church attendance) affected fertility by allowing preferential access to familyfriendly social services.

The evidence suggests that this fertility effect is due less to changing preferences or norms -the conventional wisdom-- than it is to an institutional decline which withdrew familyfriendly social services traditionally provided to Catholic communities. Otherwise it is hard to explain why the withdrawal of social service provision, as measured by nuns/capita, predicts so strongly the fertility decline of European Catholics. That interpretation is consistent with the literature linking low fertility to the lack of family-friendly institutions for the children of working mothers in contemporary Italy and other Southern European countries (Del Boca 
2002,2003). It may be that receding Church services left a vacuum in family-friendly social service provision long since filled by government in northern European countries.

Supporting evidence for this interpretation comes from Chou (2011), which studies second generation immigrants in the US: those from Catholic majority countries in Europe experienced a fertility decline well predicted by declining fertility in their parents' country of origin. Tellingly, that trans-Atlantic correlation exists even though the fertility decline in Europe occurred after their mothers' emigration.

Understanding how social service provision affects fertility may be critical to understanding fertility trends among European Catholics and to projecting European demographics over the next generation. Moreover, the implications extend beyond the halfbillion residents of Europe or even the billion Catholics worldwide. The populations and leaders of less developed countries look to Europe and wonder whether prosperity and greatly increased female labor market participation inevitably imply graying populations and demographic decline. These inferences may not be warranted if, as we find, rapid fertility decline in Catholic Europe is not so much due to economic development, female labor force participation, or even secularization, as it is due to the loss of Church-provided family-friendly social services. That finding has important public policy implications. Religious groups may strongly support social service provision in some times and places, but very different institutional arrangements may be required to support their continued provision in changing or different cultures. Our conclusions might therefore be important for any society facing rapid economic and social change, and especially for societies in which women are increasingly torn between labor market opportunities and the high shadow cost those impose on child care. That tension may be much greater the less support is available from religious communities, other social networks, markets, or governments.

\section{References}

Adsera, Alicia, (2006). “Religion and Changes in Family-Size Norms in Developed Countries,” Review of Religious Research, 47:3, 271-286, (March). (July). (2006). “Marital Fertility and Religion in Spain,” Population Studies, 60:2, 205-221,

Ahn, N., and Mira P., (2002), “A note of the relationship between fertility and female employment rates in developed countries” Journal of the Population Economics, 14 (Spring).

Akerlof, George A., and Rachel E. Kranton, (2000). “Economics and Identity,” Quarterly Journal of Economics, 115:3, 715-53.

Akerlof, George A., and Rachel E. Kranton, (2010). Identity Economics, Princeton: Princeton U. Press. Barrett, David B. World Christian Encyclopedia. Nairobi: Oxford University Press, 1982.

Becker, Gary. (1991). A Treatise on the Family, Harvard University Press, Cambridge, MA.

Becker, Gary, and Lewis, H.G., (1973), “On the Interaction between the Quantity and Quality of Children_, Journal of Political Economy, 81

Becker, Gary, and Kevin M. Murphy. (2000). Social Economics: Market Behavior in a Social Environment. Cambridge, Mass. ; London: Belknap Press of Harvard University Press.

Bell, R. M. McCaffrey, D. F.. (2002). "Bias Reduction in Standard Errors for Linear Regression with Multi-Stage Samples,” Survey Methodology, 28(2), pp. 169-182. 
Berman, Eli. (2000). Sect, Subsidy and Sacrifice: An Economist's View of Ultra-Orthodox Jews. Quarterly Journal of Economics 115 (3):905-953.

. (2009). Radical, Religious and Violent: The New Economics of Terrorism, Cambridge: MIT Press.

Berman, E. and Stepanyan A. "How Many Radical Islamists? Indirect Evidence from Asia and Africa," UCSD mimeo, 2003.

Bettio, F., Villa, P., (1998), “A Mediterranean Perspective on the Break-down of the Relationship between Participation and Fertility” Cambridge Journal of Economics, 22, 137-171.

Bongaarts, J., (1999) “Fertility Decline in the Developed World: Where will it end?,” American Economic Review, Papers and Proceedings, 89(2), 256-260.

Bryk, Anthony S.; Lee, Valerie E. and Holland, Peter Blakeley. Catholic Schools and the Common Good. Cambridge, Mass.: Harvard University Press, 1993.

Cameron, A. Colin, Jonah B. Gelbach and Douglas L. Miller, 2008. "Bootstrap-Based Improvements for Inference with Clustered Errors," The Review of Economics and Statistics, 90(3), pp. 414-427.

Chou, Tiffany (2011) "Is Fertility Decline Contagious? Trans-Atlantic norm shifts and fertility in the post-Vatican II period,” UC San Diego mimeo.

de Laat, J., and A. Sevilla-Sanz, (2004) "Working Women, Husband's Home Time, and Lowest-Low Fertility in Europe,” Brown U. mimeo, January.

Del Boca, D., (2002), “The Effect of Child care and Part Time on Participation and Fertility of Italian Women”, Journal of Population Economics, 14.

S. Pasqua, and C. Prozanto, (2003), “Analyzing Women’s Employment and Fertility Rates in Europe: differences and similarities in Northern and Southern Europe,” CHILD mimeo.

Dolan, Jay P. (1985). The American Catholic Experience: A History from Colonial Times to the Present. 1st ed. Garden City, N.Y.: Doubleday.

Durkheim, Emile. [1915] 1965. The Elementary Forms of the Religious Life. Translated by J. W. Swain. New York, NY: Free Press.

Fialka, John J. Sisters : Catholic Nuns and the Making of America. New York: St. Martin's Press, 2003.

Froehle, Bryan and Gautier, Mary. Global Catholicism : Portrait of a World Church. Maryknoll, N.Y.: Orbis Books, 2003.

Giuliano, Paola (2007). Living Arrangements in Western Europe: Does Cultural Origin Matter? Journal of the European Economic Association, 5(5): 927-952.

Grant, Mary A. and Hunt, Thomas C. Catholic School Education in the United States : Development and Current Concerns. New York: Garland Pub., 1992.

Greeley, Andrew M. (1977). The American Catholic: A Social Portrait. New York: Basic Books. . (1989). Religious Change in America. Cambridge, MA: Harvard University Press.

Greeley, Andrew M., William C. McCready, and Kathleen McCourt. (1976). Catholic Schools in a Declining Church. Kansas City: Sheed and Ward.

Gronau, Reuben (1977). "Leisure, Home Production, and Work -the Theory of the Allocation of Time Revisited,” Journal of Political Economy, 85(6), 1099-1123.

Hoge, Dean R., and Jacqueline E. Wenger. (2003). Evolving Visions of the Priesthood : Changes from Vatican Ii to the Turn of the New Century. Collegeville, Minn.: Liturgical Press.

Hout, Michael, and Andrew M. Greeley. (1987). “The Center Doesn't Hold: Church Attendance in the United States, 1940-1984.” American Sociological Review 52 (3):325-345. 
Hunt, Thomas C.; Joseph, Ellis A. and Nuzzi, Ronald James. Handbook of Research on Catholic Education. Westport, Conn.: Greenwood Press, 2001.

Iannaccone, Laurence R. (1992). Sacrifice and Stigma: Reducing Free-Riding in Cults, Communes, and Other Collectives. Journal of Political Economy 100 (2):271-292.

_. (1999). "Religious Extremism: Origins and Consequences.” Contemporary Jewry 20:8-29.

Iannaccone, Larry (2007), Looking Backward: A Cross-National Study of Religious Trends, Working Paper presented at the Association for the Study of Religion, Economics and Culture, Tampa.

Lee, James Michael and Piveteau, Didier J. Catholic Education in the Western World. Notre Dame: University of Notre Dame Press, 1967.

Lehrer, Evelyn. (1995). The Effects of Religion on the Labor Supply of Married Women. Social Science Research 24:281-301.

Lehrer, Evelyn L. (1996). "Religion as a Determinant of Marital Fertility”. Journal of Population Economics 9 (2):173-196.

Munoz-Perez, F. (1989) “The Decline of Fertility in Southern Europe,” Population: An English Selection, 44(1), pp. 261-290.

Rosenzweig, M.R. and T. Paul Schultz, (1985) “The Demand and Supply of Births,” American Economic Review, 75 pp. 992-1015.

Sander, W. (1992) “Catholicism and the Economics of Fertility.” Population Studies 46, p.477-489.

Secretaria Status, Rationarium Generale Ecclesiae, The Vatican (various years) Annuarium Statisticum Ecclesiae, Tipografia Poliglotta Vaticana, Vatican City.

Annuario Pontificio, 1912-1976, Tipografia Poliglotta Vaticana, Vatican City

Annuario Pontificio, 1977-2002, Libreria Editrice Vaticana, Vatican City

Schoenherr, Richard A., and Lawrence A. Young. (1993). Full Pews and Empty Altars: Demographics of the Priest Shortage in United States Catholic Dioceses. Madison: University of Wisconsin Press.

Smith, Adam. (1965). An Inquiry into the Nature and Causes of the Wealth of Nations. New York: Modern Library. [Original edition, 1776.]

Stark, Rodney, Daniel P. Doyle, and Lori Kent. (1980). "Rediscovering Moral Communities: Church Membership and Crime.” In Understanding Crime: Current Theory and Research, edited by T. Hirschi and M. Gottfredson. Beverley Hills, CA: Sage.

Stark, Rodney, and Roger Finke. (2000). Acts of Faith: Explaining the Human Side of Religion. Berkeley: University of California Press.

Stolzenberg, Ross M., Mary Bair-Loy, and Linda J. Waite. (1995). "Religious Participation in Early Adulthood: Age and Family Life Cycle Effects on Church Membership”. American Sociological Review 60 (1):84-103.

Warner, Carolyn M. Confessions of an Interest Group: The Catholic Church and Political Parties in Europe. Princeton, N.J.: Princeton University Press, 2000.

Weber, Max, (1946). "The Protestant Sects and the Spirit of Capitalism," in Max Weber, From Max Weber: Essays in Sociology, trans. and ed. by H.H. Gerth and C. Writght Mills. New York: Oxford University Press.

Westoff, Charles F., and Elise F. Jones. (1979). The End of "Catholic" Fertility. Demography 16 (2):209217.

Wilde, Melissa J., (2007). Vatican II: A Sociological Analysis of Religious Change. Princeton: Princeton University Press. 


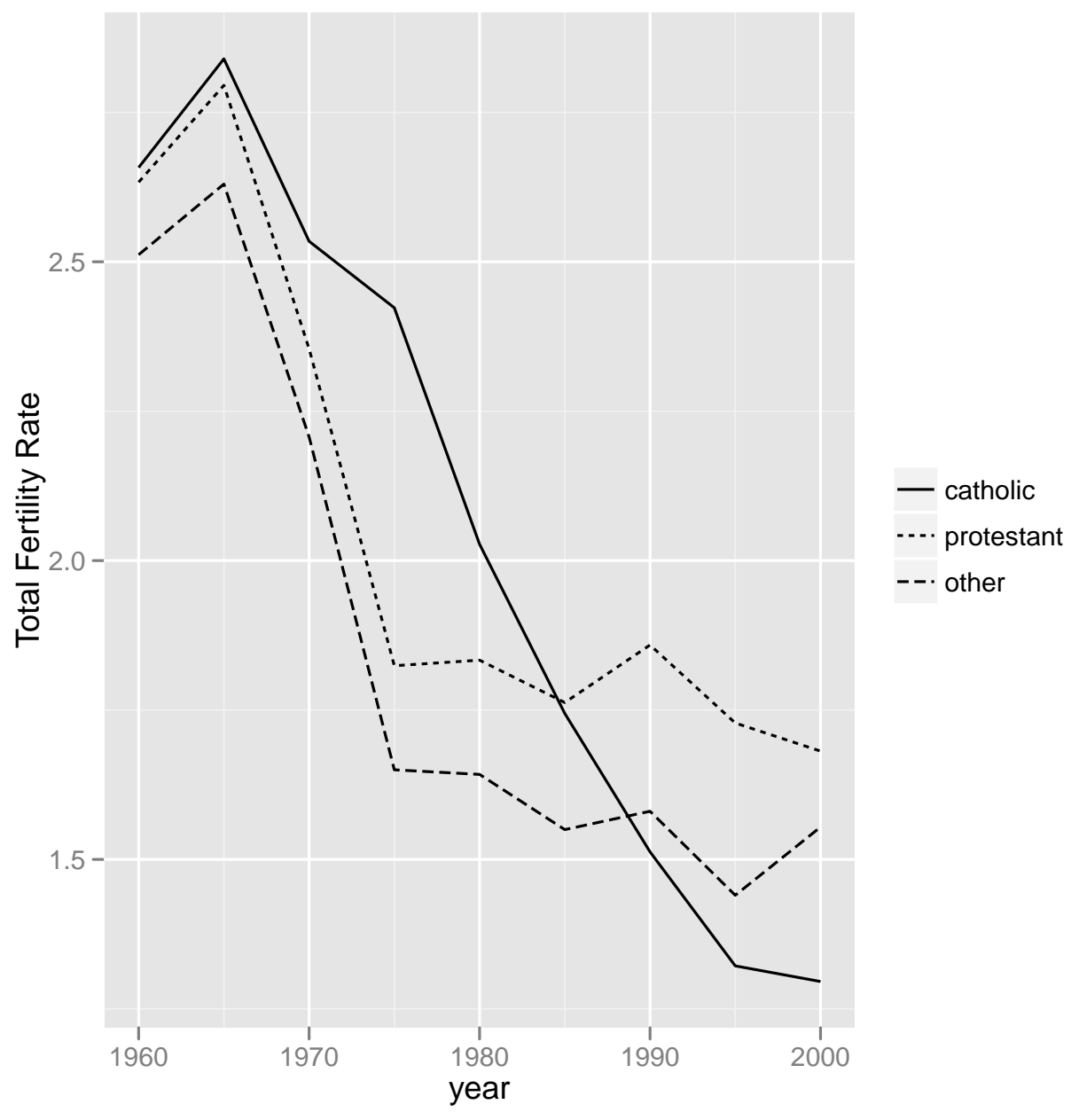

Figure 1: Western European fertility 


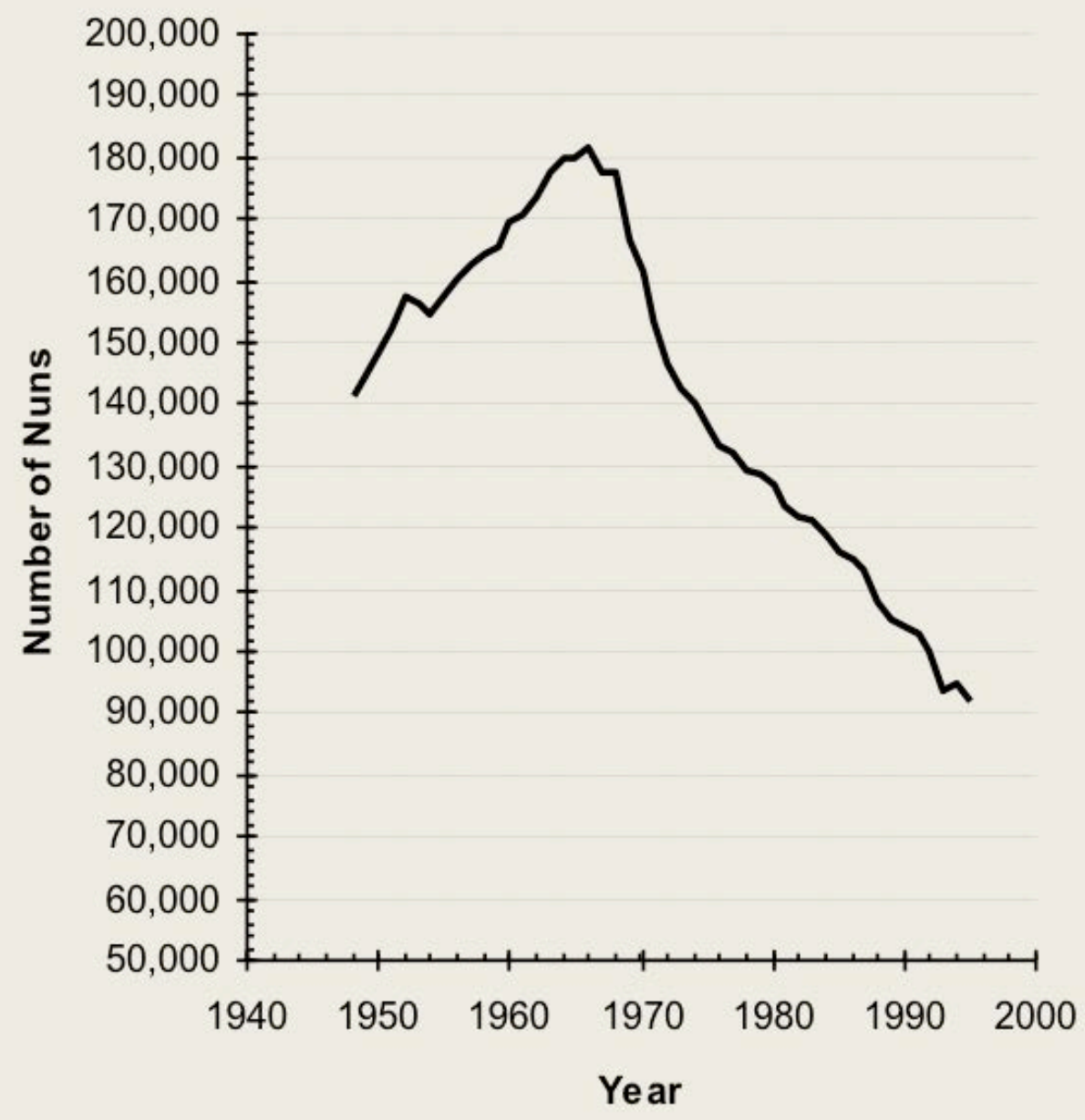

Figure 2: American Nuns Since 1948 (Source: Official Catholic Directory, from Stark and Finke, 2000) 


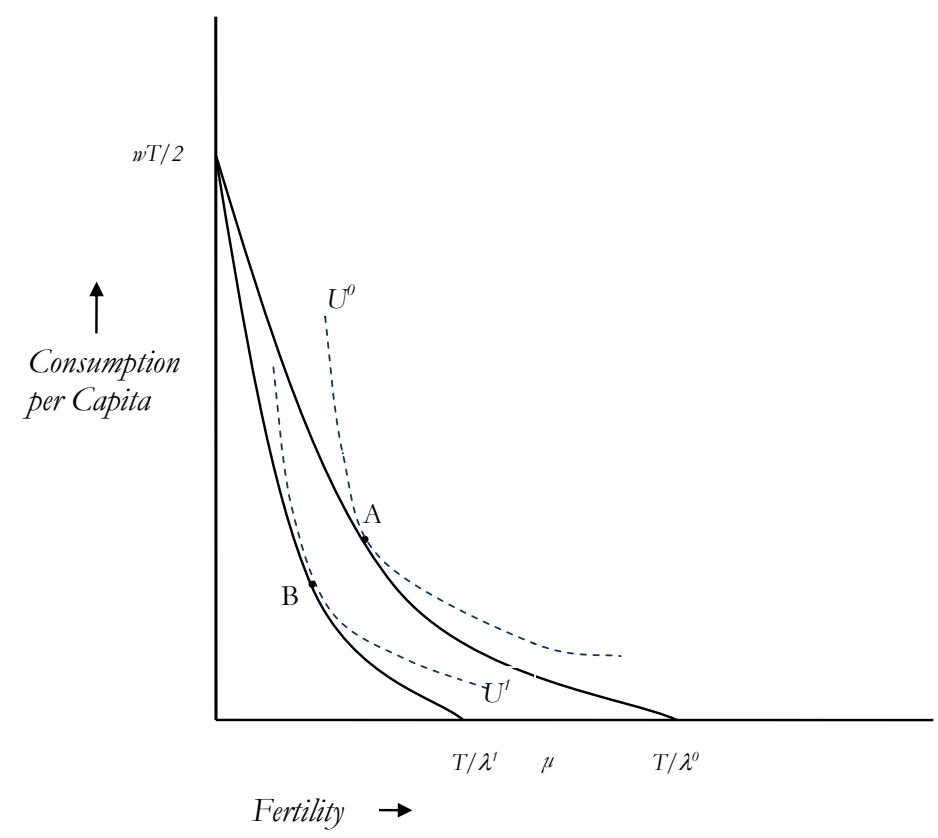

Figure 3: Fertility and childbearing costs 
** Agra (1 sett. 1886), Agraen(sis) - Metr. - Ord. d'app.: Dehli - (Indirizzo: Archbishop's House, Agra, India).

Ch. II; parr. 6; sac. d. 3 ; sem. I; sac. r. 8; sac. n. . . .; crm. I-3; crf. 4-36; iem. 7-1.436; ief. 7-1.317; iac. 5-247; catt. 3.205; ab. 11.000.000; sup. 62.160 (a. 1959).

3 Dominic Romuald Basil Athaide, dei Frati Minori Cappuccini, n. in Bandra, arcid. di Bombay, 7 febb. 1909; ord. 26 mar. 1932; el. 29 febb. 1956; cons. 20 magg. 1956.

Vicario Generale: R. P. Lawrence Colaso, O. F. M. Cap.

Agram, v. Zagreb.

Agria, v. Eger.

Agrigento (sec. 1), Agrigentin(us) - suffr. di Monreale - (Indirizzo: Vescovado, Agrigento, Italia).

Ch. 388; parr. 154; sac.d. 320; sem. 48; sac. r. 83; sac. n. 9; crm. 26-II5; crf. 68-730; iem. 22-1.250; ief. 28-r.600; iac. 54-I.538; catt. 467.520; ab. 469.864; sup. 3.042 (a. 1955).

* Grovanni Batrista Peruzzo, dei Passionisti, n. in Molare, dioc. di Acqui, 14 lu. 1878; ord. 13 genn. 1901; el. alla Ch. tit. di Eurea 18 genn. 1924; cons. 10 febb. 1924; tr. a Oppido Mamertina 19 ott. 1928 ed a q. S. I 5 genn. 1932; con titolo personale di Arciv. 29 mar. 1952 (Ass. al Soglio).

Coadiutore "sedi datus s: S. E. R. Mons. Francesco Fasola, Vesc. tit. di Vartana.

Vicario Generale: Mons. Calogero Cumbo.

Figure 4: Excerpt from the Vatican Statistical Annual (1960) 


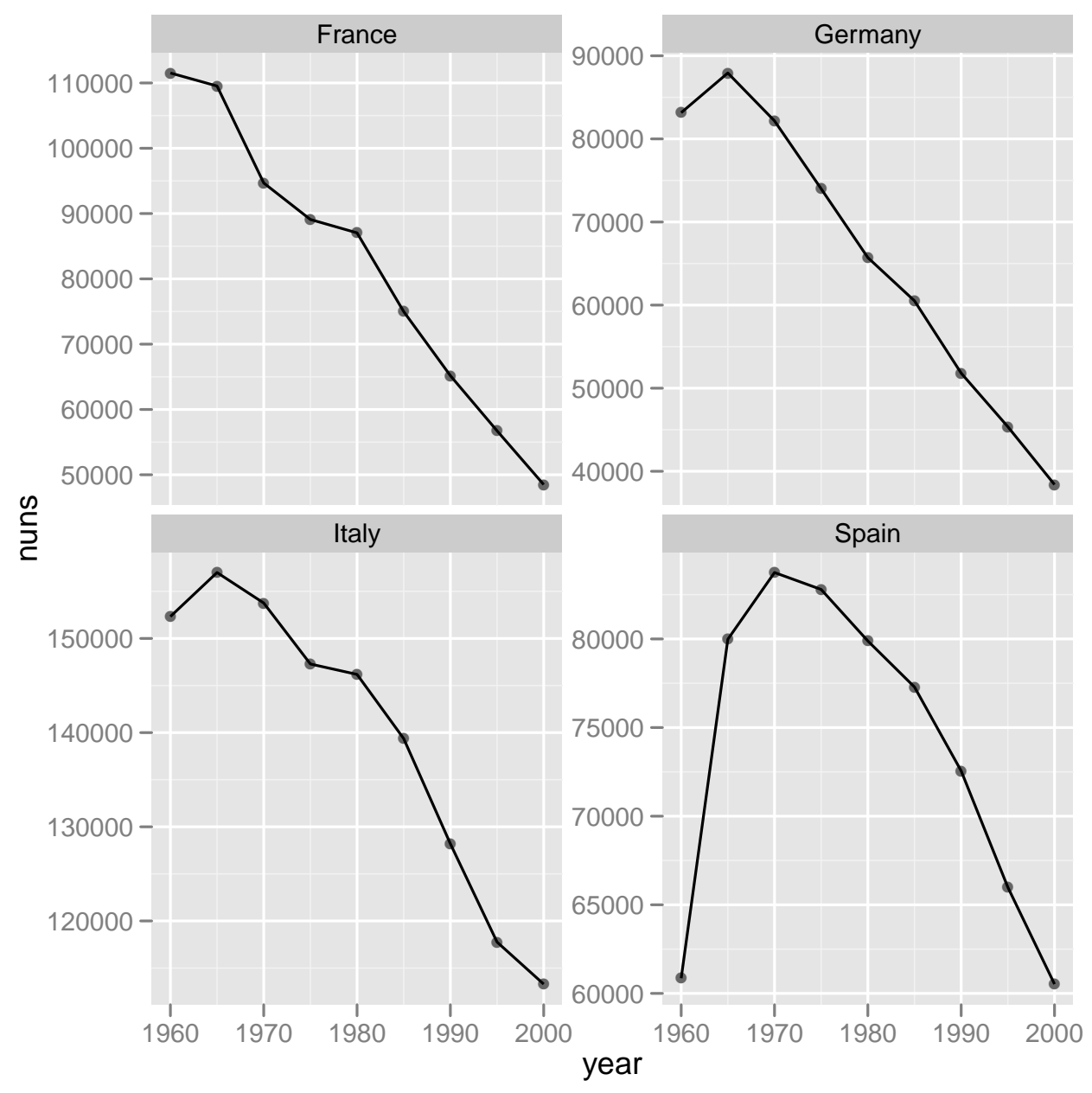

Figure 5: Nuns in France, Germany, Italy and Spain (1960-2000) 

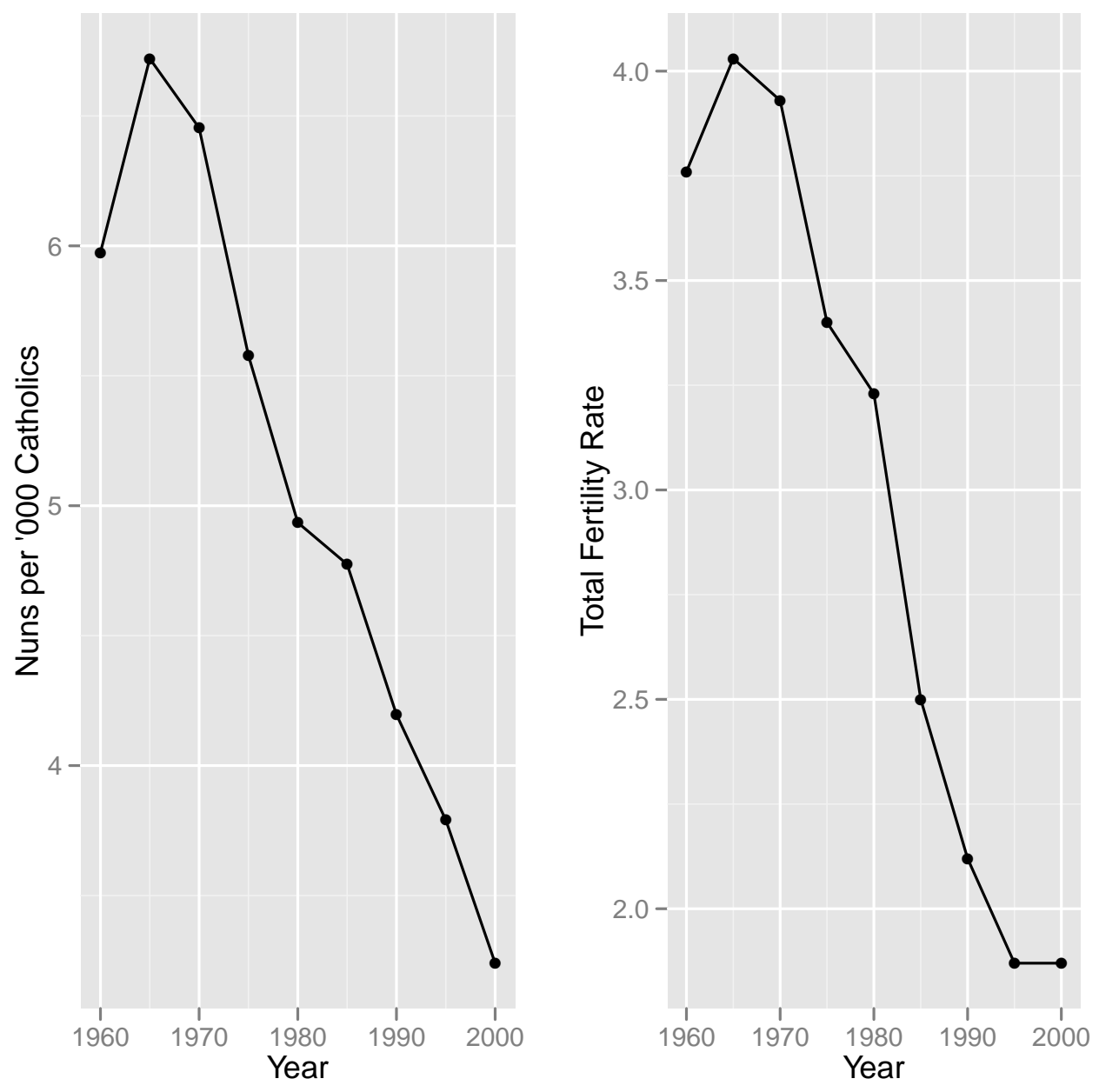

Figure 6: Fertility and Nuns/Catholic, Ireland 1960-2000 


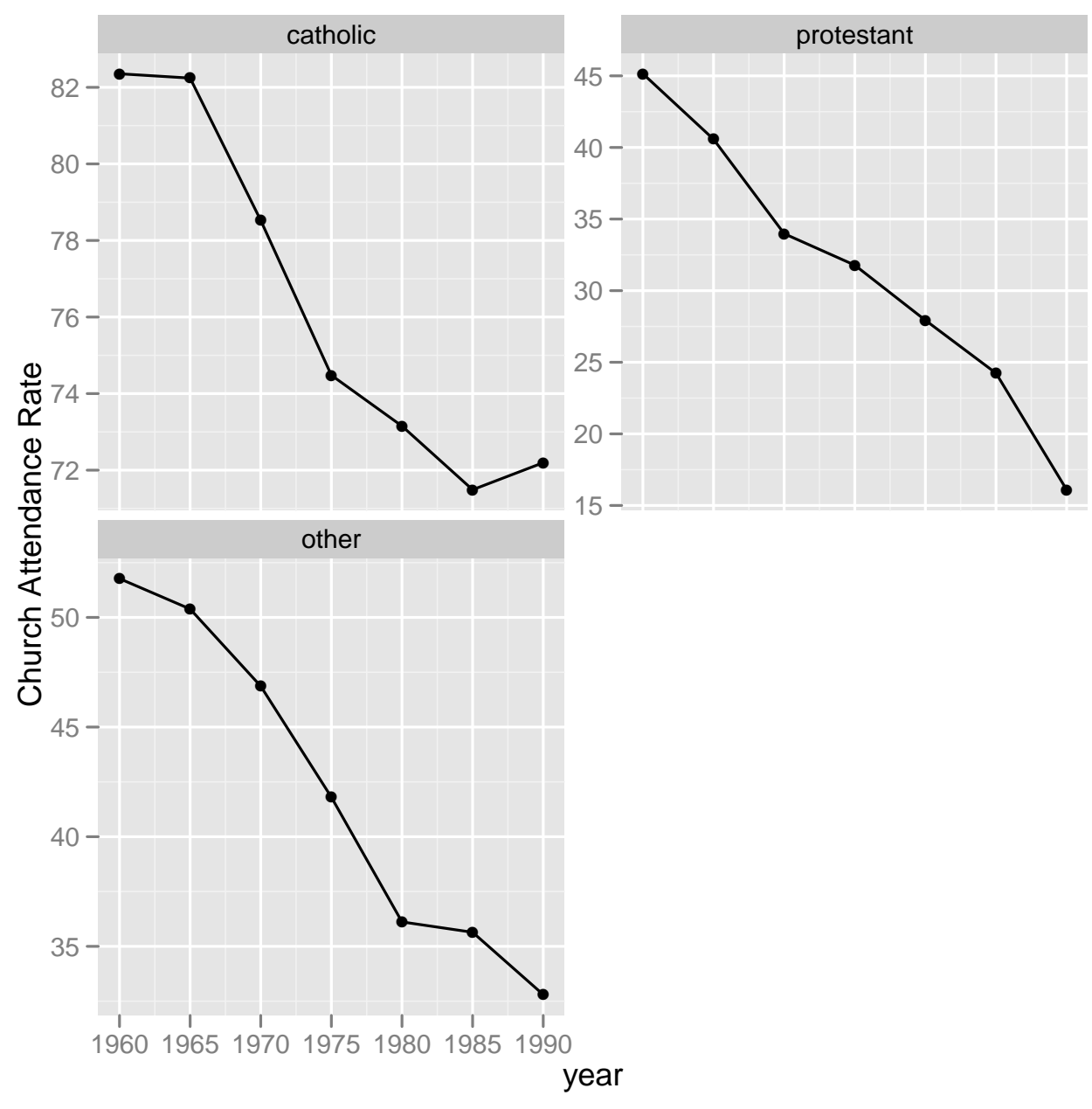

Figure 7: Church attendance by main religion: Catholic, Protestant and Other European countries 


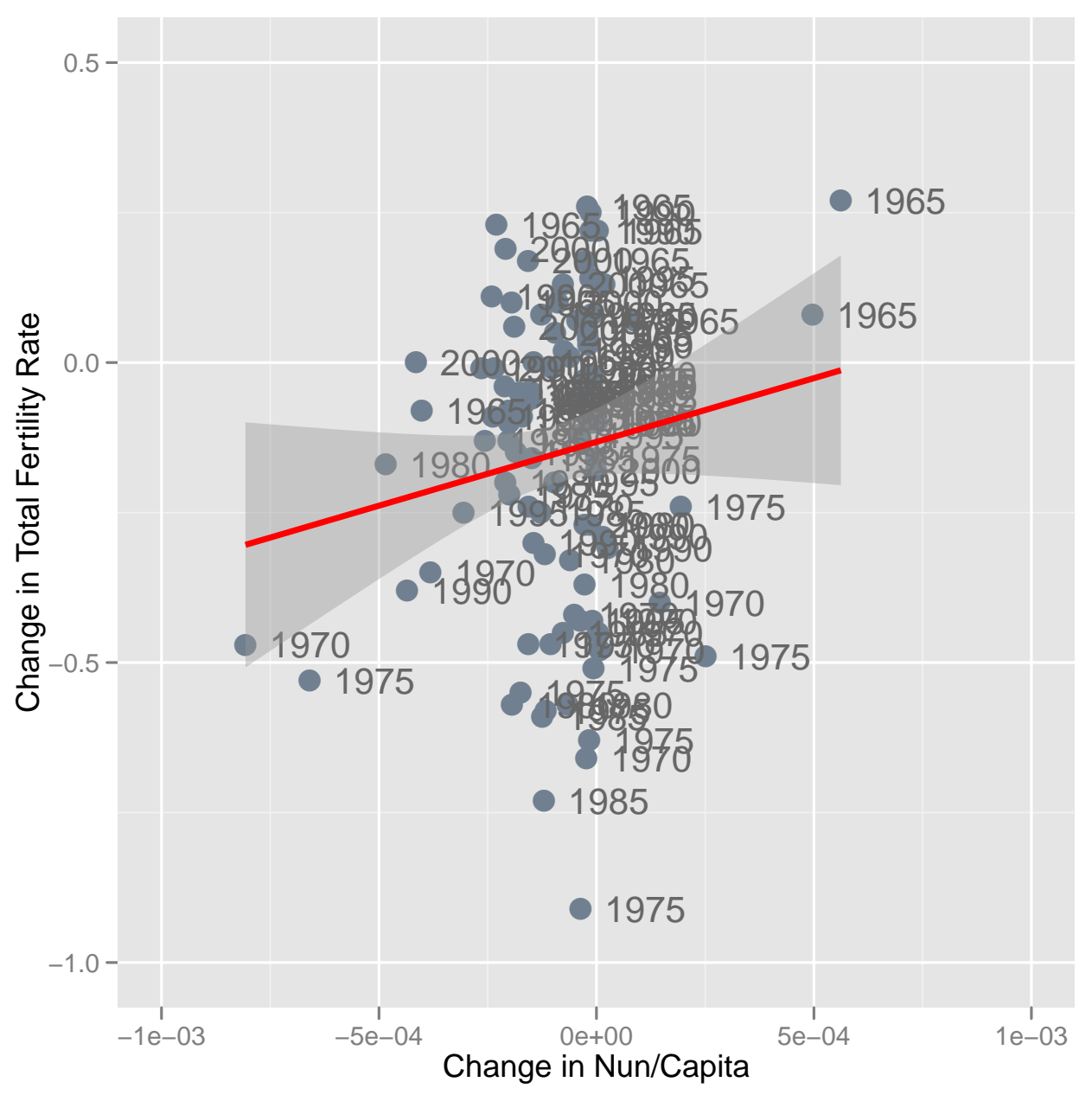

Figure 8: Change in Nun/Capita and change in Total Fertility Rate, 1960-2000 


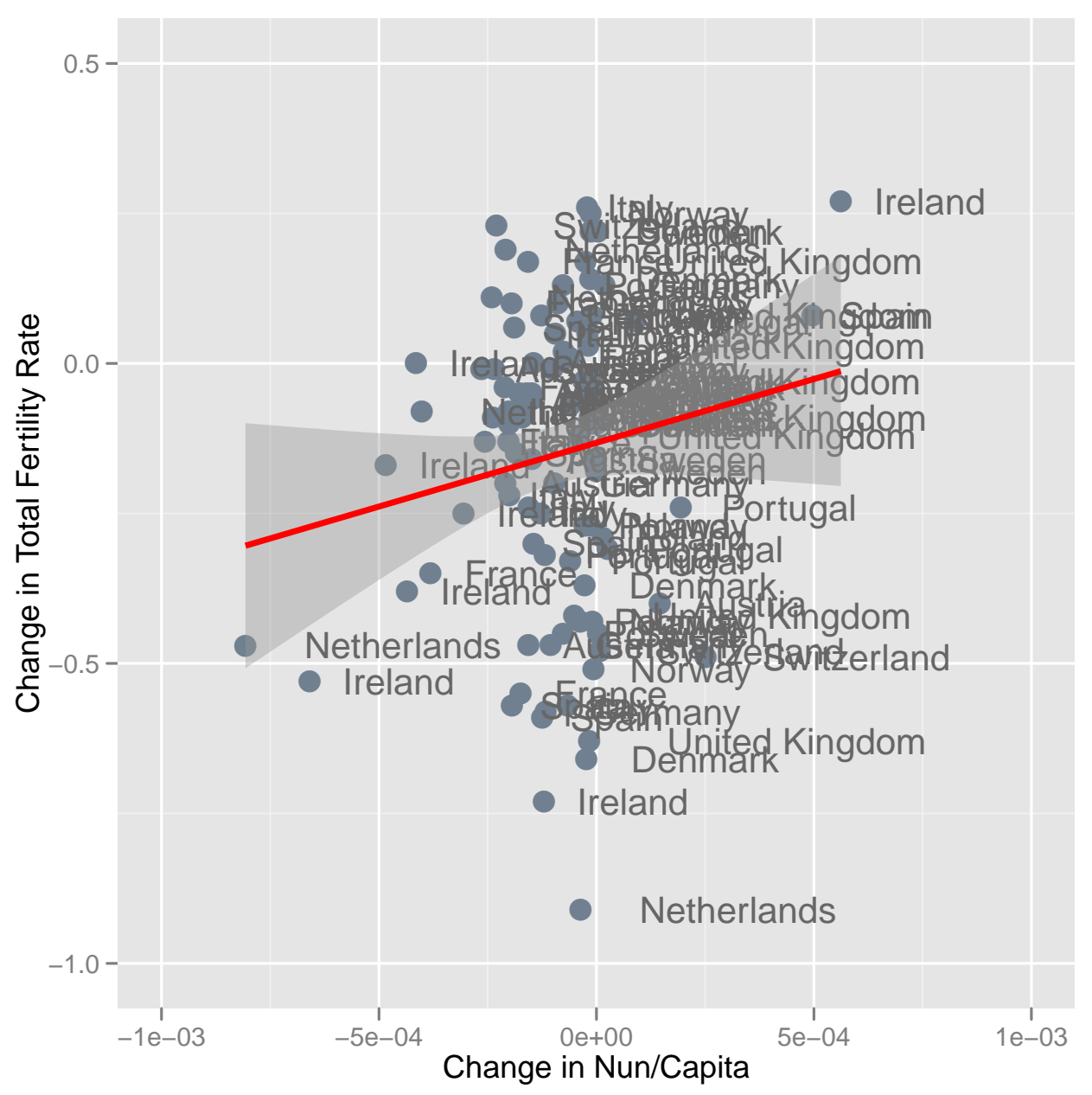

Figure 9: Change in Nun/Capita and change in Total Fertility Rate, 1960-2000 


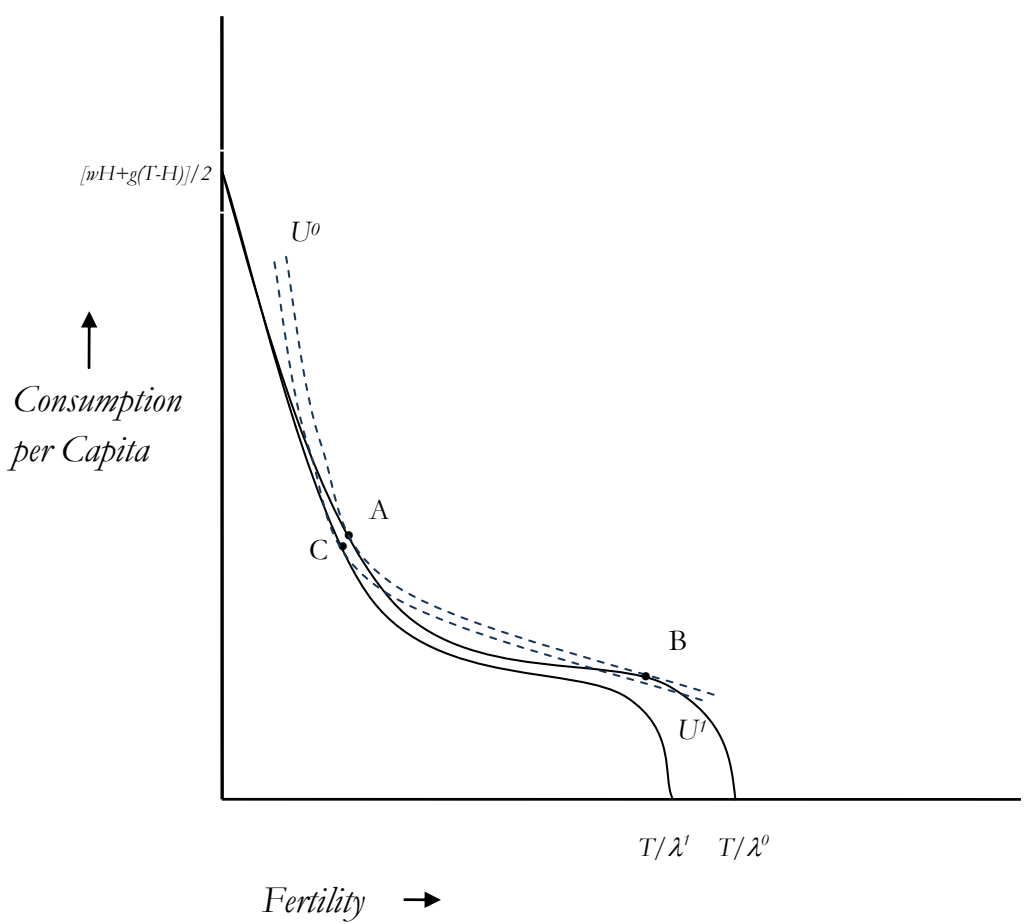

Figure 10: Fertility, childbearing costs and household production 


\begin{tabular}{|c|c|c|c|c|}
\hline & $\begin{array}{c}\% \text { Catholics } \\
(1960-2000) \text { Avg. }\end{array}$ & $\begin{array}{c}\text { Nuns } / 10000 \text { Cath } \\
1960\end{array}$ & $\begin{array}{c}\text { Nuns/10000 Cath } \\
2000\end{array}$ & $\begin{array}{c}\text { Changes in Nuns/10000 Cath } \\
1960-2000\end{array}$ \\
\hline Italy & 98 & 31 & 20 & -11 \\
\hline Spain & 97 & 21 & 15 & -6 \\
\hline Portugal & 94 & 7 & 7 & 0 \\
\hline Poland & 94 & 8 & 7 & -1 \\
\hline Austria & 85 & 22 & 9 & -13 \\
\hline France & 82 & 30 & 10 & -20 \\
\hline Ireland & 75 & 60 & 32 & -28 \\
\hline Switzerland & 47 & 36 & 18 & -18 \\
\hline Netherlands & 39 & 77 & 18 & -59 \\
\hline Germany & 36 & 32 & 13 & -19 \\
\hline United Kingdom & 9 & 37 & 15 & -22 \\
\hline Norway & 8 & 16 & 5 & -11 \\
\hline Sweden & 1 & 15 & 19 & 4 \\
\hline Denmark & 1 & 302 & 76 & -226 \\
\hline United States (1990) & 23 & \multicolumn{2}{|c|}{22 (in 1990) } & \\
\hline
\end{tabular}

Table 1: Nuns per Catholic in European Countries, 1960-2000. Number of Nuns and Catholics are from the Annuarium Statisticum Ecclasiae and from the Annuario Ponteficio. The proportion of Catholic is averaged over the period 1960-2000. U.S. figures from the Catholic Directory and ARIS, www.adherents.com.

\begin{tabular}{lccccc}
\hline \hline & Mean & Std. Dev. & Min & Max & Obs \\
\hline$\Delta$ Total Fertility Rate & -0.14 & 0.24 & -0.91 & 0.27 & 104 \\
$\Delta$ Nuns per 10000 & -1.01 & 1.24 & -8.07 & 5.62 & 104 \\
$\Delta$ Attendance rate (AR) & -2.93 & 4.17 & -15.00 & 17.00 & 78 \\
$\Delta(A R) \times$ Proportion Catholic $($ PC) & -1.54 & 2.92 & -12.23 & 6.58 & 78 \\
$\Delta(A R) \times$ Nuns per 10000 (NC) & -89.13 & 124.45 & -633.07 & 488.84 & 78 \\
$\Delta(A R)_{t-15}$ & -2.66 & 3.52 & -15.00 & 5.00 & 104 \\
$\Delta(A R)_{t-15} \times(P C)$ & -1.45 & 2.65 & -12.23 & 4.71 & 104 \\
$\Delta(A R)_{t-15} \times(N C)$ & -89.22 & 112.23 & -681.66 & 550.68 & 104 \\
$\Delta$ Female LFP & 2.24 & 2.03 & -2.79 & 13.42 & 104 \\
\hline
\end{tabular}

Table 2: Changes in Fertility, Attendance and Nuns. Summary statistics 1960, 5 year intervals. Population weighted. Fertility and female labor force participation are from the World Bank. Nuns, and Catholics are from the Vatican Statistical Annual (1970-2000) and from the Annuario Pontificio (1960-1970). The proportion Catholic is averaged over the period 1960-2000. The 14 countries included are those listed in Table 1 above, except for the U.S. Church attendance rates are calculated using the ISSP data retrospectively, as in Iannaccone (2003). Contemporaneous attendance rates are available only through 1990. 


\begin{tabular}{|c|c|c|c|c|c|c|}
\hline & $(1)$ & (2) & (3) & (4) & (5) & (6) \\
\hline Nuns per capita & & & & \multicolumn{3}{|c|}{$407.90^{* * *} 365.05^{* * *} 383.24^{* *}$} \\
\hline & & & & (123.69) & $(119.28)$ & $(117.02)$ \\
\hline \multirow[t]{2}{*}{ Church attendance rate } & 0.00 & -0.01 & -0.01 & & -0.01 & -0.01 \\
\hline & $(0.01)$ & $(0.01)$ & $(0.01)$ & & $(0.01)$ & $(0.01)$ \\
\hline \multicolumn{7}{|l|}{ Church attendance } \\
\hline \multirow[t]{2}{*}{$\times$ proportion Catholic } & & $0.02^{* * *}$ & * $0.03^{* * *}$ & & $0.02^{* *}$ & $0.02^{* *}$ \\
\hline & & $(0.01)$ & $(0.01)$ & & $(0.01)$ & $(0.01)$ \\
\hline \multicolumn{7}{|l|}{ Female } \\
\hline \multirow[t]{2}{*}{ labor force participation } & & & -0.01 & & & $-0.02^{*}$ \\
\hline & & & $(0.01)$ & & & $(0.01)$ \\
\hline Constant & $\begin{array}{c}-0.156 \\
(0.023)\end{array}$ & $\begin{array}{c}-0.159 \\
(0.023)\end{array}$ & $\begin{array}{c}-0.126 \\
(0.025)\end{array}$ & $\begin{array}{c}-0.134 \\
(0.019)\end{array}$ & $\begin{array}{c}-0.127 \\
(0.024)\end{array}$ & $\begin{array}{r}-0.0837 \\
(0.029)\end{array}$ \\
\hline$N$ & 82 & 82 & 82 & 78 & 78 & 78 \\
\hline
\end{tabular}

Table 3: Fertility, Church Attendance and Nuns. For variable definitions see note to Table 2. Standard errors are clustered by country. Weighted by population. Values in parenthesis are clustered (by country) standard errors. $* * *$ $p<0.01,{ }^{* *} p<0.05, * p<0.1$.

Note: Calculating standard errors and statistical significance is complicated by the small number of countries in the sample (14) so that asymptotic approximations rely on the $N \times T$ rather than $N$. We report standard errors clustered by country over time. They are corrected by the jacknife-equivalent procedure proposed by Bell and McCaffrey (2002), which corresponds to the $C R 3$ standard errors of Cameron, Gelbach, and Miller (2008). Critical values used to mark statistical significance are those of a t-distribution with 13 (the number of countries minus one) degrees of freedom. We have validated the statistical significance of these results using the alternative "wild bootstrap" procedure of Cameron, Gelbach and Miller (2008), which is designed to treat the same problem, but has lower power. Rejection probabilities (p-values) using that procedure are quite similar in general. The two cases in which they differ are noted in footnotes to the text. 


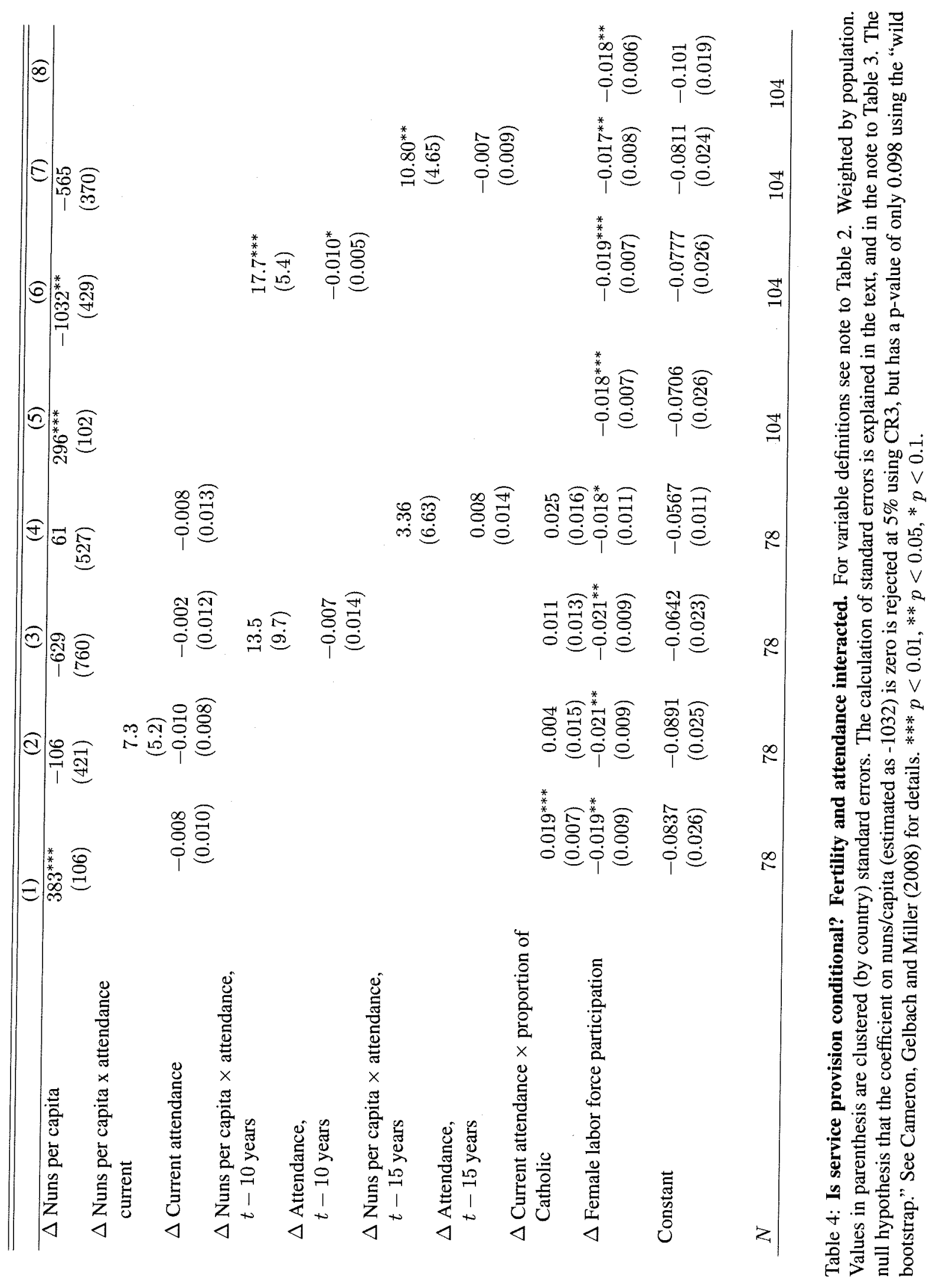




\begin{tabular}{lcccccc}
\hline & $(1)$ & $(2)$ & $(3)$ & $(4)$ & $(5)$ & $(6)$ \\
\hline$\Delta$ Priests per capita & & 556.65 & -669.76 & & 146.76 & -866.26 \\
& & $(1012.80)$ & $(1522.36)$ & & $(761.30)$ & $(1108.62)$ \\
$\Delta$ Nuns per capita & $383.24^{* * *}$ & & 508.22 & $296.09^{* *}$ & $485.47^{*}$ & $(260.57)$ \\
& $(117.02)$ & & $(314.39)$ & $(111.67)$ & & $(26)^{* *}$ \\
$\Delta$ Female labor force participation & $-0.02^{*}$ & -0.02 & -0.02 & $-0.02^{* *}$ & $-0.02^{* *}$ & $-0.02^{* *}$ \\
& $(0.01)$ & $(0.01)$ & $(0.01)$ & $(0.01)$ & $(0.01)$ & $(0.01)$ \\
$\Delta$ Current attendance & -0.01 & -0.01 & -0.01 & & & \\
& $(0.01)$ & $(0.01)$ & $(0.01)$ & & & \\
$\Delta$ Current attendance $\times$ proportion of & & & & & & \\
Catholic & $0.02^{* *}$ & 0.02 & $0.02^{*}$ & & & \\
& $(0.01)$ & $(0.01)$ & $(0.01)$ & & & \\
Constant & -0.0837 & -0.11 & -0.0876 & -0.0706 & -0.0975 & -0.0723 \\
& $(0.029)$ & $(0.025)$ & $(0.024)$ & $(0.028)$ & $(0.028)$ & $(0.024)$ \\
$N$ & & & & & 104 & 104 \\
\hline
\end{tabular}

Table 5: Which Services Affect Fertility? Priests and Nuns. For variable definitions see note to Table 2. Weighted by population. Values in parenthesis are clustered (by country) standard errors. The calculation of standard errors is explained in the text, and in the note to Table 3. The null hypothesis that the coefficient on nuns/capita in column (6) (estimated as 485.47 ) is zero is rejected at $10 \%$ using CR3, but has a p value of only 0.13 using the wild bootstrap. See Cameron, Gelbach and Miller (2008) for details. ${ }^{* * *} p<0.01,{ }^{* *} p<0.05, * p<0.1$. 


\section{Appendix}

\begin{tabular}{lcccc}
\hline & $(5)$ & $(6)$ & $(5 \mathrm{bis})$ & $(6 \mathrm{bis})$ \\
\hline Nuns per capita & $365.048^{* * *}$ & $383.236^{* * *}$ & 347.047 & 414.903 \\
& $(119.279)$ & $(117.024)$ & $(241.185)$ & $(243.505)$ \\
Church attendance rate & -0.006 & -0.008 & 0.029 & 0.020 \\
& $(0.008)$ & $(0.011)$ & $(0.027)$ & $(0.028)$ \\
Church attendance & & & & \\
$\quad \times$ proportion Catholic & $0.019^{* *}$ & $0.019^{* *}$ & -0.007 & -0.002 \\
& $(0.007)$ & $(0.008)$ & $(0.020)$ & $(0.021)$ \\
Female & & & & $-0.030^{*}$ \\
$\quad$ labor force participation & & $-0.019^{*}$ & & $(0.015)$ \\
& & $(0.010)$ & & -0.0389 \\
Constant & -0.127 & -0.0837 & -0.0951 & $-0.11)$ \\
& $(0.024)$ & $(0.029)$ & $(0.1)$ & $(0.1)$ \\
$N$ & & & & \\
& & & & 40 \\
\hline
\end{tabular}

Table A.1: Fertility, Church Attendance and Nuns. The results reported in column (5) and in column (6) correspond to those reported in Table 3. The models reported in column (6bis) and in column (7bis) are estimated using only observations from the $1960-1975$ period.

\begin{tabular}{lcccc}
\hline & $(5)$ & $(6)$ & $(5 \mathrm{bis})$ & $(6 \mathrm{bis})$ \\
\hline Nuns per capita & $365.048^{* * *}$ & $383.236^{* * *}$ & $476.389^{* *}$ & $552.404^{* * *}$ \\
& $(119.279)$ & $(117.024)$ & $(164.921)$ & $(170.124)$ \\
Church attendance rate & -0.006 & -0.008 & 0.004 & -0.003 \\
& $(0.008)$ & $(0.011)$ & $(0.010)$ & $(0.011)$ \\
Church attendance & & & & \\
$\quad \times$ proportion Catholic & $0.019^{* *}$ & $0.019^{* *}$ & -0.000 & 0.003 \\
Female & $(0.007)$ & $(0.008)$ & $(0.009)$ & $(0.010)$ \\
$\quad$ labor force participation & & $-0.019^{*}$ & & $-0.033^{* *}$ \\
& & $(0.010)$ & & $(0.014)$ \\
Constant & & & & \\
& -0.127 & -0.0837 & -0.147 & -0.0734 \\
& $(0.024)$ & $(0.029)$ & $(0.038)$ & $(0.047)$ \\
$N$ & & & & \\
\hline
\end{tabular}

Table A.2: Fertility, Church Attendance and Nuns. The results reported in column (5) and in column (6) correspond to those reported in Table 3 . The models reported in column (6bis) and in column (7bis) are estimated using only observations from the $1960-1980$ period. 